\title{
KARST BREAKDOWN MECHANISMS FROM OBSERVATIONS IN THE GYPSUM CAVES OF THE WESTERN UKRAINE: IMPLICATIONS FOR SUBSIDENCE HAZARD ASSESSMENT
}

\author{
Alexander KLIMCHOUK and Vjacheslav ANDREJCHUK
}

\begin{abstract}
The term karst breakdown is employed in this paper to denote the totality of processes and phenomena of gravitational and/or hydrodynamic destruction of the ceiling of a karst cavity and of the overlying sediments. It refers not only to the existence of a surface subsidence (collapse) feature but, first of all, to the "internal" (hidden in the subsurface) structures that precede development of a surface form.

This study reports and discusses the results of direct mapping and examination of breakdown structures in the gypsum karst of the Western Ukraine, at the level of their origin, i.e. in caves. The accessibility of numerous laterally extensive maze cave systems in the region provided an excellent opportunity for such an approach, which made it possible to examine the relationship between breakdown structures and particular morphogenetic or geological features in caves, and to reveal stages of breakdown development.

It is found that breakdown is initiated mainly at specific speleogenetically or geologically "weakened" localities, which classify into a few distinct types. The most of breakdowns, which are potent to propagate through the overburden, relate with the outlet cupolas/domepits that represent places where water had discharged out of a cave to the upper aquifer during the period of transverse artesian speleogenesis. Distribution of breakdown structures does not correlate particularly well with the size of the master passages. Several distinct mechanisms of breakdown development are revealed, and most of them proceed in several stages. They are guided by speleogenetic, geological and hydrogeological factors.

The study confirms that a speleogenetic approach is indispensable to the understanding of breakdown pre-requisites and mechanisms, as well as for eventual subsidence hazard assessment. Direct observations in caves, aimed both at speleogenetic investigation and breakdown characterization on regional or site-specific levels, should be employed wherever possible.
\end{abstract}

KEYWORDS: karst subsidence, karst breakdown mechanisms, gypsum caves, speleogenesis, subsidence hazard assessment

\section{Introduction}

The term karst breakdown is used in this paper to denote the totality of processes and phenomena of gravitational and/or hydrodynamic destruction of the ceiling of a karst cavity and of the overlying sediments. Use of this more general concept avoids potential misconceptions that commonly arise from the ambiguous use of terms "col- 
lapse" and "subsidence" in the literature. It has an additional advantage in that it does not refer to the existence of a surface subsidence (collapse) feature and includes "internal" (hidden in the subsurface) processes and phenomena that precede the appearance of a surface form.

Karst breakdown is complex, consisting of a number of processes, with components developing in various combinations, either simultaneously or sequentially. Some components may dominate during certain stages of the breakdown development, whereas others may occur throughout the entire process. The karst breakdown mechanism is understood here as a combination of specific component processes in a regular sequence, and their development in time and space.

An understanding of the karst breakdown mechanisms is crucial to subsidence hazard assessment, prediction and management in karst terraines. A set of component agencies and a shifting of the breakdown process proper (i.e. breakdown mechanism) depends on many factors and conditions, a combination of which is referred to here as "settings". Analysis of the available literature on the subject suggests that the most important factors that determine settings are: 1) the presence and structure of the overburden, 2) lithological (geotechnical) properties of individual units in the cover, 3) hydrogeological conditions (especially piezometric levels and hydraulic gradients), and 4) degree of karstification and characteristics of the primitive initiating cavities.

Numerous accessible and laterally extensive cave systems in the Western Ukrainian gypsum karst provide excellent opportunities for direct examination and mapping and examination of breakdown structures at the level of their origin, i.e. in caves. Such observations and surveys are indispensable for an adequate understanding of conditions favorable to breakdown initiation and of mechanisms favorable to their development.

\section{Geological and hydrogeological background to gypsum karst develop- ment}

The Miocene gypsum sequence is widespread on the southwestern edge of the eastern European platform, along the Carpathian Foredeep, where it occupies over $20,000 \mathrm{~km}^{2}$. Gypsum stretches from the northwest to southeast for more than $300 \mathrm{~km}$ as a belt ranging from several kilometers to 40 to $80 \mathrm{~km}$ wide (Fig. 1A). It is the main component of the Miocene evaporite formation that girdles the Carpathian folded region to the northeast, from the Nida river basin in Poland across the Western Ukraine and Moldova to the Tazleu river basin in Romania.

Most Miocene rocks along the platform margin rest on the eroded terrigenous and carbonate Cretaceous sediments. The Miocene succession comprises deposits of Badenian (Tortonian) and Sarmatian age. The Lower Badenian unit, beneath the gypsum, includes mainly carbonaceous, argillaceous and sandy beds (30-90 m thick) adjacent to the foredeep, and these grade into rocks of calcareous biohermal and sandy facies (10-30 m thick) towards the platform interior. The overlying gypsum bed is variable in structure and texture. Most commonly it grades from microcrystalline massive gypsum at the lower part through variably grained bedded gypsum in the middle to giantocrystallline rock in the upper horizon. A layer of evaporitic and epigenetic limestone, locally called "Ratynsky", commonly overlies the gypsum, 


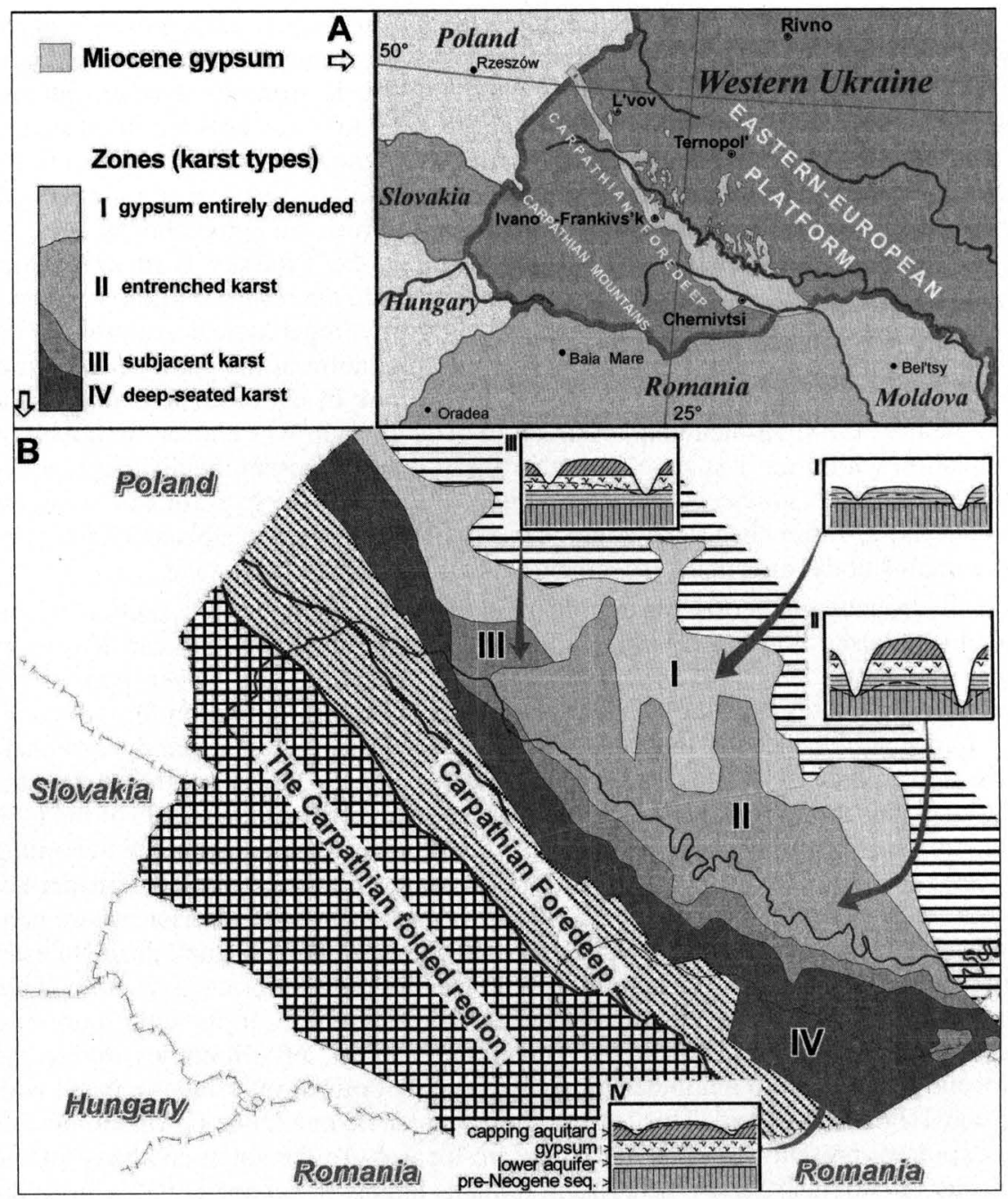

Fig. 1 - Location of the gypsum karst of the Western Ukraine $(A)$ and zonation of the region according to evolutionary types of karst $(B)$. Zones of different karst types are labeled by Roman numbers: $I=$ the gypsum is entirely denuded, $I I=$ entrenched karst, $I I I=$ subjacent karst, $I V=$ deep-seated (confined) karst

ranging from half a meter to more than $25 \mathrm{~m}$ in thickness. The gypsum and the Ratynsky limestone comprise the Tyrassky Formation which is overlain by the Upper Badenian unit represented either by argillaceous and marly lithothamnion limestones and sandstone beds or, adjacent to the foredeep, by marls and clays of the Kosovsky formation. The latter grades upward into the Lower Sarmatian clays. The total thickness of the capping marls and clays ranges from $40-60 \mathrm{~m}$ in the platform interior to 80-100 $\mathrm{m}$ and more in the areas adjacent to the regional faults that separate the platform edge from the foredeep. 
There is a distinct trend in the depth of the gypsum occurrence, position of the overall denudation surface within the Miocene succession and the depth of erosional entrenchment in the direction across the gypsum belt, from the platform interior towards the foredeep. The Tyrassky Formation dips 1 to $3^{\circ}$ towards the foredeep and is disrupted by block faults in the transition zone. To the south and south-west of the major Dniester Valley, large tectonic blocks drop down as a series of steps, the thickness of clay overburden increases, and the depth of erosional entrenchment decreases. Along the tectonic boundary with the foredeep the Tyrassky Formation drops down to the depth of $1000 \mathrm{~m}$ and more. This variation, the result of differential neotectonic movement, played an important role in the hydrogeological evolution of the Miocene aquifer system and resulted in the differentiation of the platform edge into the four zones (Andrejchuk, 1984, 1988; Klimchouk et al, 1985; Klimchouk and Andrejchuk, 1988; Klimchouk, 1996, 2000). The gypsum was entirely removed by denudation within the 1-st zone, but other three zones represent the distinct types of karst: entrenched, subjacent and deep-seated (Fig. 1-B). The gypsum bed is largely drained in the entrenched karst zone, is partly inundated in the subjacent karst zone and remains under artesian confinement in the deep-seated karst zone.

In hydrogeologic terms the region represents the southwestern portion of the Volyno-Podolsky artesian basin (Shestopalov, 1989). The Sarmatian and Kosovsky clays and marls serve as an upper confining sequence. The lower part of the Kosovsky Formation and the limestone bed of the Tyrassky Formation form the original upper aquifer (above the gypsum) and the Lower Badenian sandy carbonate beds, in places along with Cretaceous sediments, form the lower aquifer (below the gypsum), the latter being the major regional one. The hydrogeologic role of the gypsum unit has changed with time, from initially being an aquiclude, intervening between two aquifers, to a karstified aquifer with well-developed conduit permeability (Klimchouk, 2000). Regional flow is from the platform interior, where confining clays and the gypsum are largely denuded, toward the large and deep Dniester Valley and the Carpathian foredeep. In the north-west section of the gypsum belt the confined conditions (zone IV) prevail across its entire width. In its wide south-east section the deeply incised valleys of Dniester and its left tributaries divide the Miocene sequence into a number of isolated deeply drained interfluves capped with the clays (Podol'sky area). This is the entrenched karst zone (zone II) where most of the explored, presently relict maze caves are located. To the south-southeast of the Dniester (Bukovinsky area) the gypsum remains largely intact and is partly inundated (the subjacent karst zone - III). Further in this direction, as the as the depth of the gypsum occurrence below clays increases and entrenchment decreases, the Miocene aquifer system becomes confined (the deep-seated karst zone - IV). In this zone the groundwater flow pattern includes a lateral component in the lower aquifer (and in the upper aquifer but to a lesser extent) and an upward component through the gypsum in areas of potentiometric lows, where extensive cave systems develop as evidenced by numerous data from exploratory drilling.

\section{Speleogenesis}

Fourteen large caves over $1 \mathrm{~km}$ in length are known in the region. Most of these caves are presently relict. They are located north of the Dniester, within the 2 nd zone 
Table 1. Parameters of large caves and cave fields in the Western Ukraine

\begin{tabular}{|c|c|c|c|c|c|c|}
\hline No & Cave name* & $\begin{array}{c}\text { Development, } \\
\mathrm{m}\end{array}$ & $\begin{array}{l}\text { Specific volume } \\
\mathrm{m}^{3} / \mathrm{m}\end{array}$ & $\begin{array}{l}\text { Density of } \\
\text { passages, } \\
\mathrm{km} / \mathrm{km}^{2}\end{array}$ & $\begin{array}{c}\text { Areal } \\
\text { coverage, } \\
\% \\
\end{array}$ & $\begin{array}{c}\text { Cave } \\
\text { porosity, } \\
\%\end{array}$ \\
\hline \multicolumn{7}{|c|}{ The Podol'sky sub-region } \\
\hline 1 & Optimistychna & 214000 & 2.8 & 147 & 17.6 & 2.0 \\
\hline 2 & Ozerna & 111000 & 6 & 150 & 44.6 & 5.0 \\
\hline 3 & Mlynki & 25000 & 3.3 & 141 & 37.6 & 3.4 \\
\hline 4 & Kristalna & 22000 & 5.0 & 169 & 29.2 & 6.0 \\
\hline 5 & Slavka & 9100 & 3.7 & 139 & 27.6 & 3.4 \\
\hline 6 & Verteba & 7800 & 6.0 & 118 & 34.7 & 12.0 \\
\hline 7 & Atlantida & 2520 & 4.5 & 168 & 30.0 & 4.0 \\
\hline 8 & Ugryn & 2120 & 3.8 & 177 & 33.3 & 5.7 \\
\hline 9 & Jubilejna & 1500 & 2.3 & 278 & 37.0 & 4.0 \\
\hline 10 & Komsomol'ska & 1240 & 2.1 & 177 & 24.3 & 3.0 \\
\hline 11 & Dzhurinska & 1130 & 2.4 & 126 & 17.8 & 2.0 \\
\hline \multicolumn{7}{|c|}{ The Bukovinsky sub-region } \\
\hline 12 & Zoloushka & 92000 & 8.0 & 142 & 48.4 & 3.8 \\
\hline 13 & Bukovinka & 2400 & 2.5 & 120 & 21.5 & 4.4 \\
\hline 14 & Gostry Govdy & 2000 & 1.7 & 270 & 17.5 & 4.0 \\
\hline \multicolumn{2}{|r|}{ Totals } & 493820 & - & - & - & - \\
\hline \multicolumn{2}{|r|}{ Averages } & - & 3.9 & 164 & 29.5 & 4.5 \\
\hline
\end{tabular}

* The names are given here according to the Ukrainian spelling. In many other publications Russian spelling is common, where most of names ended here with " $a$ ", end with "-skaja" or "aja".

(entrenched karst). Two other large caves, Zoloushka and Bukovinka, are in the Bukovinsky sub-region, near the Prut River, generally in the area of artesian flow within the Miocene aquifer system (4th zone) but within local, exceptionally uplifted blocks, where entrenchment into the upper part of the gypsum caused unconfined (water table) conditions to be established during the Holocene.

All the large gypsum caves in the region are mazes arranged into laterally extensive multi-storey networks, which have developed along vertical and steeplyinclined fissures. Interconnecting passages form lateral two- to four-storey systems that extend over areas of up to $1.5 \mathrm{~km}^{2}$. Such areas, termed here cave fields, are defined by drawing an arbitrary boundary closely enclosing the passages on a cave map. Significant morphological parameters of the caves are summarized in Table 1. Figs. 5A, 10, 11 and 12 illustrate some typical cave patterns.

Optimistychna Cave, with more than $214 \mathrm{~km}$ of surveyed passages, is the longest gypsum cave and the second longest cave of any type known in the world. The 
Western Uraine contains the five longest known gypsum caves in the world, accounting for well over half of the total known length of gypsum caves on the Earth. By area and volume the largest caves are Ozernaja $\left(330,000 \mathrm{~m}^{2}\right.$ and $\left.665,000 \mathrm{~m}^{3}\right)$ and Zoloushka $\left(305,000 \mathrm{~m}^{2}\right.$ and $\left.712,000 \mathrm{~m}^{3}\right)$, followed by Optimisticheskaja Cave $\left(260,000 \mathrm{~m}^{2}\right.$ and $\left.520,000 \mathrm{~m}^{3}\right)$.

The absolute parameters of cave systems change as exploration progresses. Specific parameters are more informative. Specific volume (the cave volume/length ratio, which is in fact the average area of passage cross-section) characterizes an average size of cave passages in a cave system. For the caves of the region this parameter ranges from 1.7 (Gostry Govdy Cave) to 8.0 (Zoloushka Cave) $\mathrm{m}^{3} / \mathrm{m}$. The average value for the region is $3.9 \mathrm{~m}^{3} / \mathrm{m}$. Passage network density is characterized conveniently by using the ratio of cave length to a unit area of the cave field $\left(\mathrm{km} / \mathrm{km}^{2}\right)$. This parameter varies within the region from 118 (Verteba Cave) to 278 (Jubilejnaja Cave) $\mathrm{km} / \mathrm{km}^{2}$, with an average value of $164 \mathrm{~km} / \mathrm{km}^{2}$.

The availability of detailed morphometrical data on caves and host rock bodies allows calculation of areal coverage and cave porosity parameters (fractions of the total area and the volume of the rock within a cave field occupied by passages). The areal coverage varies from 17.5 to $48.4 \%$, the average value being of $29.5 \%$. Cave porosity varies from 2 to $12 \%$, with an average value of $4.5 \%$.

Maze caves in the region have been developed (and are presently developing in the 4th zone) under confined conditions, due to upward transverse groundwater circulation between the sub-gypsum and supra-gypsum aquifers (Klimchouk, 1990, 1992, 1996, 2000). Such a flow pattern is characteristic of potentiometric low areas, related to topographic lows (valleys), which commonly coincide with zones of enhanced fluid conductivity created within the capping clays by tectonic or stratigraphical discontinuities. Overall discharge from artesian aquifer systems occurs in such areas. Under conditions of transverse circulation in a multi-storey artesian system, all available fissures in the gypsum, which hold similar positions within analogous flow paths, enlarge at comparable rates because of the availability of dispersed aggressive recharge from below and suppressed hydraulic competition due to constrained outflow. This behavior generally favors the development of maze cave structures, but the actual conduit arrangement in any given locality depends upon the initial fissure pattern.

Three major components can be distinguished in the cave systems based on shape, arrangement and hydrologic function of cave mesoforms during the main (artesian) speleogenetic stage (Figs. 2 and 3):

1. Feeder channels, the lowermost components in a system: vertical or sub-vertical conduits through which water rose from the sub-gypsum aquifer to the master passage networks. Such conduits are commonly separate but sometimes they form small networks at the lowermost part of the gypsum, along the top of the underlying bed. The feeder channels join master passages located at the next upper level and are scattered rather uniformly through their networks.

2. Master passages: horizontal passages that form laterally extensive networks within certain horizons in the middle part of the gypsum bed. They received dispersed recharge from numerous feeder channels and conducted flow laterally to the nearest outlet feature.

3. Outlet features: domes, cupolas and vertical channels (domepits) that rise from 


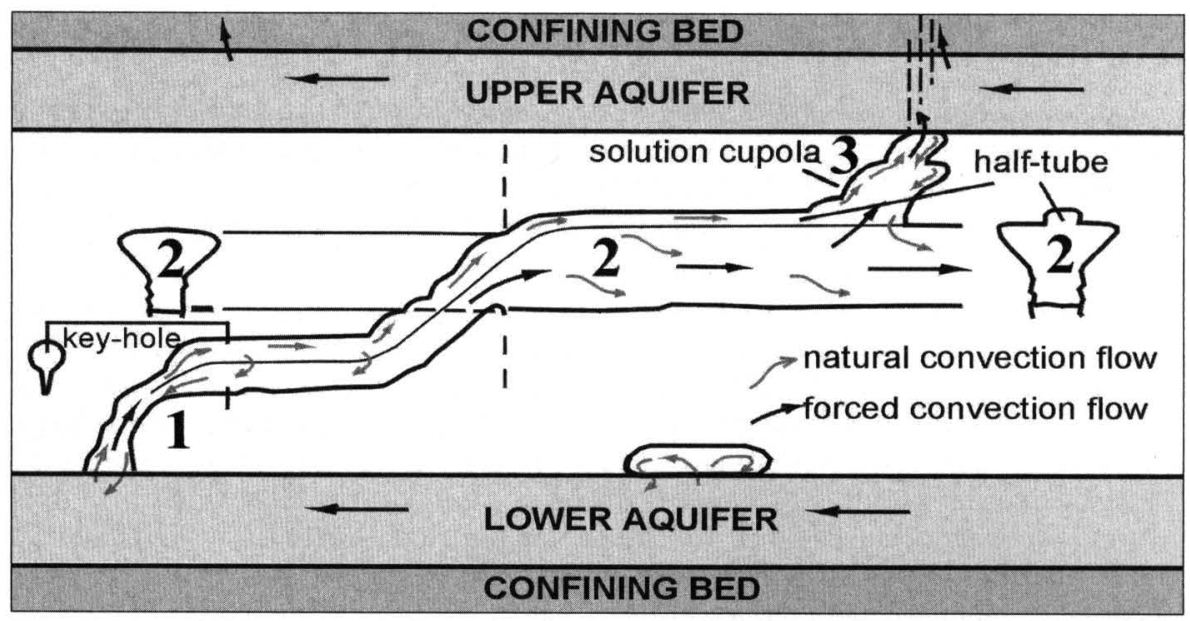

Fig. 2 - Main morphogenetic features of maze cave systems in the Western Ukraine shown at their hydrologic functionality. 1 = feeder channels, $2=$ master passages, $3=$ outlet features
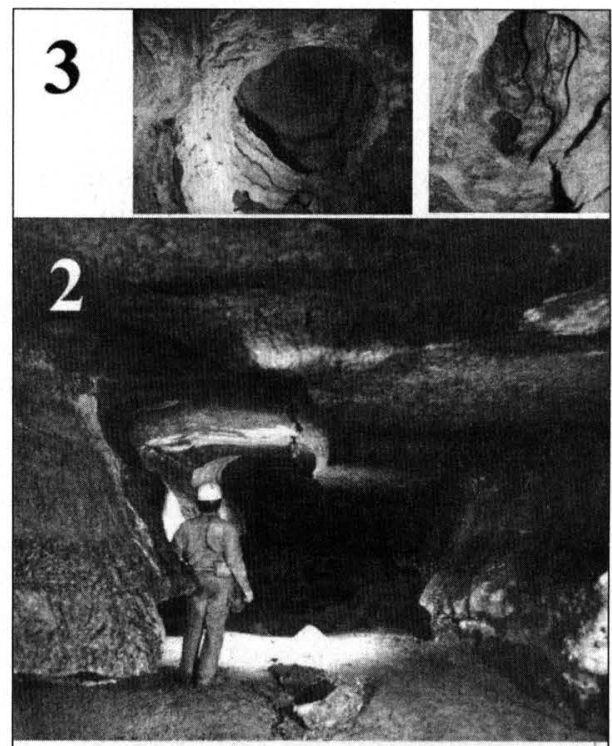

Fig. 3 - Examples of typical morphogenetic features in the caves:

1 = feeder channels, Mlynki and Ozerna caves;

2 = master passage, Dzhurinska cave;

$3=$ outlet features, Slavka and Optimistycha caves. Photo by A.Klimchouk.

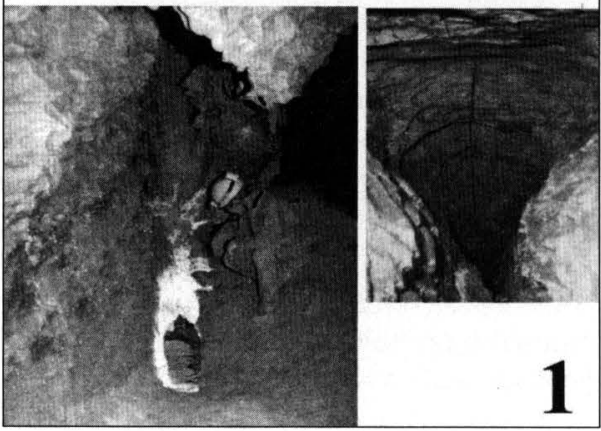


the ceiling of the master passages to the bottom of the overlying bed. They discharged water from cave systems to the overlying aquifer.

Other typical features formed under modern entrenched karst conditions are vertical dissolution pipes, which grow due to a focused descending percolation from the overlying formations. They are 1 to $3 \mathrm{~m}$ wide, extend downwards through the full thickness of the gypsum from its top, and are commonly superimposed upon relict artesian passages.

The Western Ukrainian maze caves provide the most outstanding and unambiguous evidence for the transverse artesian speleogenetic model. Artesian speleogenesis in the Podol'sky sub-region took place during the Late Pliocene through Early Pleistocene when the overall maze structure of caves became established. Breaching of artesian confinement and further incision of the valleys during the Middle Pleistocene caused substantial acceleration of groundwater circulation within the Miocene artesian system. The majority of passage growth, as well as breakdown formation, probably occurred during this transitional period. Where the water table was established in the gypsum for a prolonged time, further widening of passages occurred. Eventually, with the lowering of the water table below the lower gypsum contact, cave systems in the entrenched karst zone became entirely fossilized. Cave development under confined or semi-confined conditions continues today within the zones of deep-seated and subjacent karst (the 4th and 3rd zones).

\section{Speleological observations of the breakdown formation and devel- opment: methods and criteria}

The accessibility of numerous laterally extensive cave systems in the Western Ukrainian gypsum karst provides an excellent opportunity for direct mapping and examination of breakdown structures at the level of their origin. This allows almost all breakdown structures, which have evolved within a cave field, to be mapped, including those that are still hidden within the coverbeds and not manifested on the surface. Such mapping makes it possible to investigate the relationship of breakdown structures with particular morphogenetic and geologic features in a cave and to reveal stages of breakdown development. The state (quasi-equilibrium or non-equilibrium) of a breakdown structure can be judged and a degree of its propagation toward the surface through the cover (the height of a breakdown column - the depth of a migrating void below the surface) can be determined. Together with detailed data on lithostratigraphy, thickness and hydrogeology of the overburden, this reveals the breakdown mechanisms and facilitates subsidence hazard assessment for the respective areas with a precision and certainty unachievable by the approaches of conventional engineering geology. Such investigations make it possible to test the validity and adequacy of various indirect approaches to subsidence hazard assessment and the assumptions on which such approaches are based.

The following features were identified and mapped as breakdown structures in the caves (Fig.4):

1) Any outlet features (domes, cupolas and domepits in cave passages) indicating considerable breakout in the vault. Breakdown is identified by predominantly gravitational morphology of the vault and by the presence of disarticulated fragments of bedrock and coverbed materials beneath it.

2) Breakdown taluses in cave passages consisting of the fallen bedrock and 

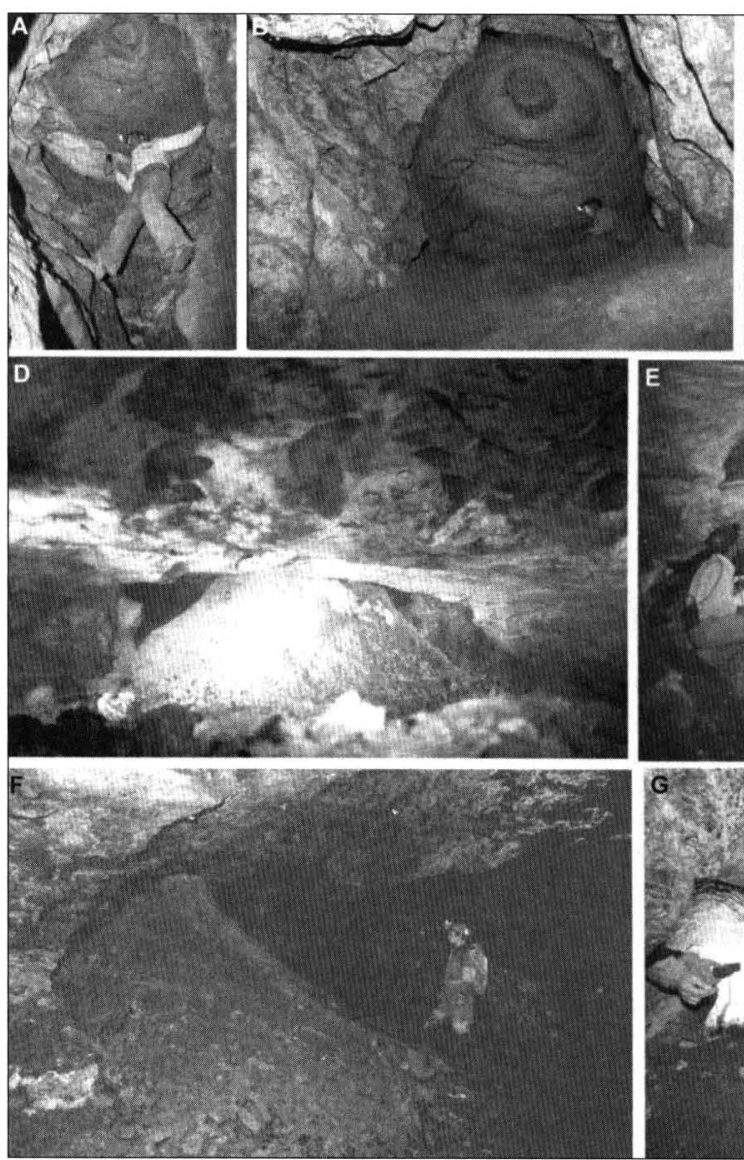
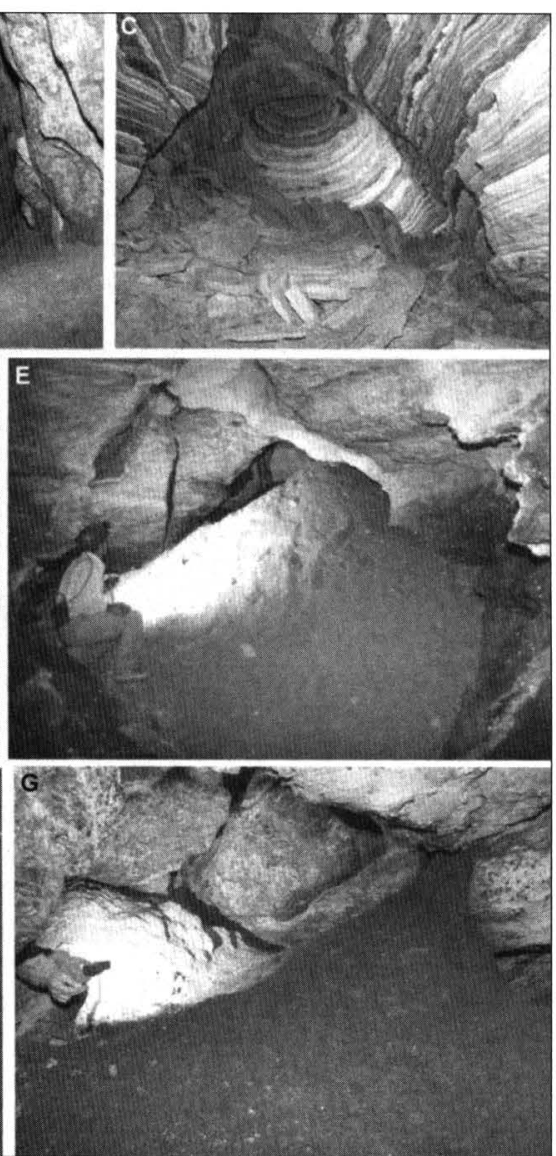

Fig. 4 - Breakdown structures in the caves. Breakout cupolas: $A$ and $B=$ in Mlynki cave, $C=$ in Slavka cave. Breakdown piles: $D=$ in Kievljanka cave, $E=$ in Mlynki cave, $F=$ in Zoloushka cave, $G=$ in Verteba cave. Photo by A.Klimchouk.

coverbed material. Depending on the initial dome diameter and the distance of upward stoping, such taluses can plug an access to the breakout cupola and separate the migrating void from the cave.

Breakdown structures in the Western Ukrainian gypsum karst normally develop in a number of stages through a prolonged period of time. The multi-stage development is determined by the stratified nature of the overburden which has varying lithological, geomechanical and hydrogeological properties of individual units. The stages are identified from a position of a cupola or a migrating void within the cover that, if not directly observed, can be inferred in most cases from the size, shape and composition of breakdown taluses. The state (quasi-equilibrium or non-equilibrium) of a breakdown structure can be additionally determined from the presence or absence of signs of recent activity in a breakdown talus (water seepage or flow, dampness of sediments, signs of creep or extrusion, etc.). 
Such surveys were performed in several caves developed in different geological and hydrogeological settings and representing different morphological character: in Zoloushka Cave (subjacent karst settings), Mlynki, Slavka and Verteba caves (entrenched karst settings).

\section{Breakdown development in the subjacent karst zone: Zoloushka Cave and the Dankivsky Collapse}

Zoloushka Cave (Fig. 5A) is the third longest gypsum cave in the world with $92 \mathrm{~km}$ of passages mapped since 1976 when few entrances were opened in the face of an active gypsum quarry. The cave area lies generally in the confined karst zone, although in some of the more uplifted tectonic blocks (where the gypsum was partially entrenched by the nearby major Prut Valley during the Holocene) the groundwater surface is some 2 to $3 \mathrm{~m}$ below the gypsum top. The quarry operation and accompanied groundwater withdrawal since 1950 s caused the water table to further drop 17 -to $19 \mathrm{~m}$ below the gypsum top and brought about considerable transformations in the karst system. The cave was thoroughly studied in various aspects (Andrejchuk, 1984, 1988, 1999; Andrejchuk and Korzhik, 1984) and provides an excellent playground for examination of karst breakdown mechanisms.

\subsection{Local settings}

Local geomorphological and geological settings are depicted on Fig. 5, B and C. The gypsum in the cave area has a thickness of 23 to $25 \mathrm{~m}$, being overlain by the microcrystalline grey - light brown Ratynsky limestone, up to $1 \mathrm{~m}$ thick. The Kosovsky Formation, 5 to $60 \mathrm{~m}$ in thickness (depending on the local relief), spreads over the cave area. It comprises mainly argillaceous sediments of grayish-blue color, with some minor sandstone and limestone beds in its lower part. The clays consist predominantly of montmorillonite (up to $38 \%$ ) and hydro-illite (25 to $30 \%$ ), and are massive in the lower part of the formation and thinly-bedded in the upper part. The main geotechnical characteristics of the clay are as follows: natural humidity - 17 to $18 \%$, plasticity index -28 , density $-2.1 \mathrm{~g} / \mathrm{cm}^{3}$, skeletal volume weight $-1.77 \mathrm{~g} / \mathrm{cm}^{3}$, porosity $-35.6 \%$. Above the Kosovsky Clays the Quaternary alluvium of the upper (III to IV) Prut terraces is present, comprising sandy-gravel (immediately above the Kosovsky Clays) and loam sediments. The loams, ranging from a few to $19 \mathrm{~m}$ in thickness, are light and porous. The soil layer, 0.5 to $1.2 \mathrm{~m}$ thick and rich in humus (2.7 to $6.4 \%$ ), lies on the top.

The gypsum rests on the sands and marls of the Lower Badenian (3 -to 4m), which in turn overly the eroded Cretaceous limestones and sandstones. Together they form the presently unconfined aquifer, which also includes the lower part of the gypsum. Under natural conditions the aquifer discharged to the Prut River through the terrace sediments. During the quarrying stage a depression cone due to water withdrawal from the quarry deformed the groundwater surface in the cave area. The Quaternary aquifer is also present, being perched on the Kosovsky Clays, although in the cave area it is increasingly drained by breakdown structures that disrupt the clay succession.

\subsection{Dewatering of the cave}

The quarry that opened the cave started at the end of 1940s. Since then, groundwaters have been continuously abstracted from the quarry and a drawdown cone has 


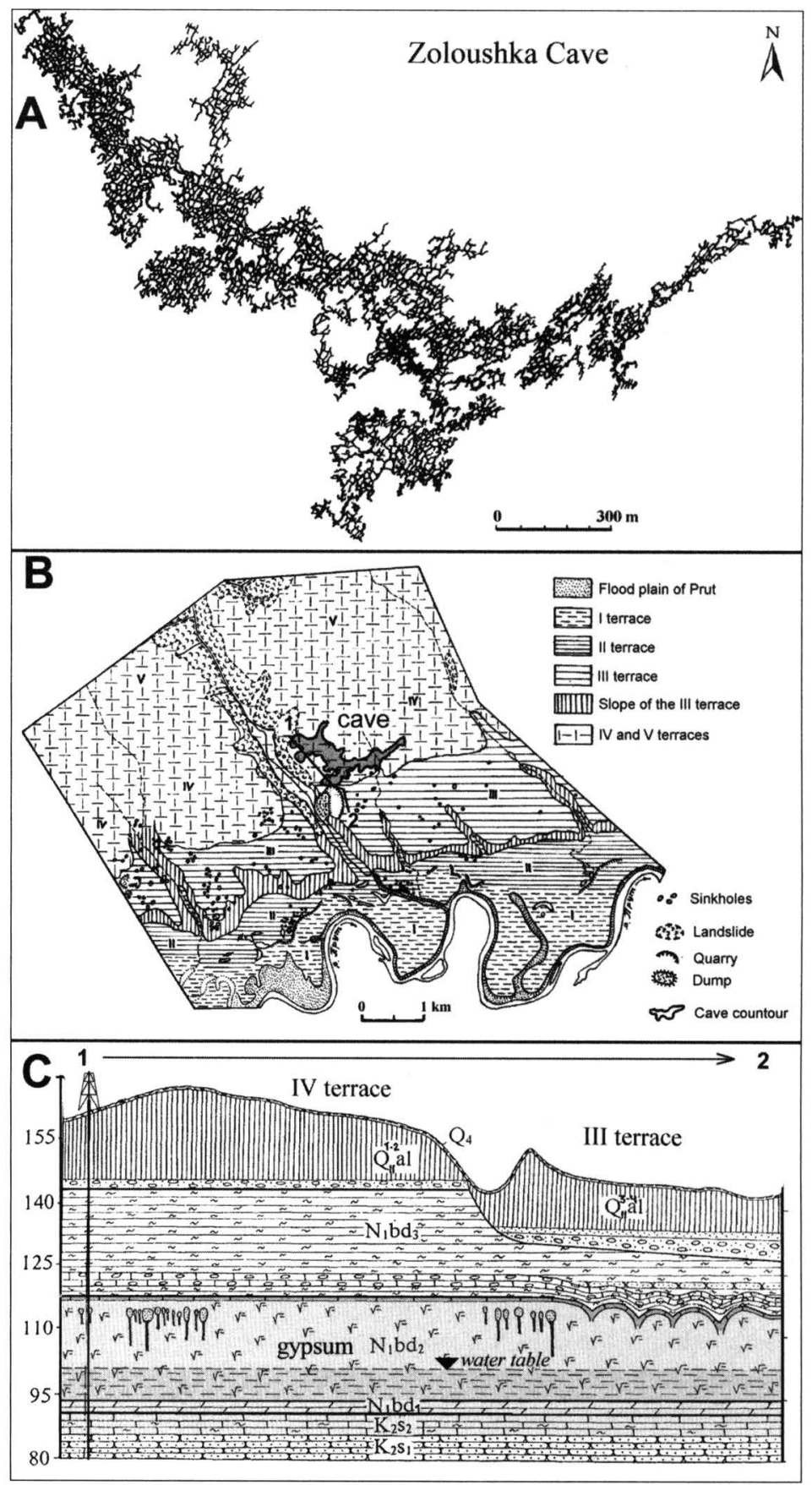

Fig. 5 - A = The map of Zoloushka cave (courtesy of the Chernovitsky Speleological Club), B $=$ Geomorphological map of the area, $C=$ Geological cross-section across the cave field. 
formed around it. In the beginning the withdrawal rate was rather modest amounting about 20 to $50 \mathrm{~m}^{3} /$ hour. When the quarry had deepened up to 8 to $10 \mathrm{~m}$, the pumping rates increased to 100 to $500 \mathrm{~m}^{3} /$ hour. Since the mid- $1960 \mathrm{~s}$, with the cutting of the third quarry bench to the depth of 18 to $22 \mathrm{~m}$, groundwater inflow reached 700 to $800 \mathrm{~m}^{3} /$ hour and this rate was maintained until nowadays.

Before the quarry, the groundwater level had been situated at about 2 to $3 \mathrm{~m}$ below the gypsum top, some 1 to $2 \mathrm{~m}$ below the ceiling of Zoloushka's upper storey passages. The groundwaters circulated slowly toward the Prut River and discharged through the alluvium. They contained considerable amount of $\mathrm{H}_{2} \mathrm{~S}$ and dissolved solids ( 3.0 to $4.5 \mathrm{~g} / \mathrm{L}$ ). With the start of the operations, the quarry became the drainage focus. Within the drawdown cone that expanded up to several kilometers in diameter, groundwater flow changed to radial, with a considerable increase of flow rates, decrease of TDS content (up to 1.9 to $2.6 \mathrm{~g} / \mathrm{L}$ ) and $\mathrm{H}_{2} \mathrm{~S}$ degassing.

The lowering of the piezometric surface and dewatering of the cave had progressed most during the 1960s. In the first period of the cave exploration (1976 to 1978) passage bottoms were covered by "fresh" wet slippery clay, progressively desiccating and shrinking in the following years with overall decrease in volume and the formation of characteristic crack patterns. The floor level in most passages has lowered by 1 to $2 \mathrm{~m}$ and the volume of passages has increased by 25 to $35 \%$ since the time of the first exploration. This apparently contributed to an activation of the preexisting breakdown structures that rested on the cave fill. The lower storey of the cave remains inundated, being located below the water table.

\subsection{Cave morphology}

Zoloushka Cave is a labyrinth of horizontal passages occurring in two storeys. The upper storey consists predominantly of large passages (average width and height are respectively $2.8 \mathrm{~m}$ and $3.0 \mathrm{~m}$; specific volume is $8.0 \mathrm{~m} 3 / \mathrm{m}$ ) with ceilings located 1 to $3 \mathrm{~m}$ below the gypsum top (Fig. 6A and B). Their cross-sections are oval, rhomb-like or hemispherical. Numerous solution domes ( 1 to $5 \mathrm{~m}$ in diameter) in the passage ceilings expose the overlying Ratynsky limestone bed. Such domes were outlets for the water to the overlying aquifer during the period of transverse artesian speleogenesis. In some areas large closely spaced passages coalesce laterally, with only small pillars remaining in between them (Fig. 6C). This is due to horizontal notching by preferential dissolution at the water table during the Holocene (Fig. 6B and C). In this way some quite large $\left(15,000\right.$ to $\left.30,000 \mathrm{~m}^{3}\right)$ chambers were formed. In areas where the level of clay filling lowers, it is possible to observe 3 to $10 \mathrm{~m}$-deep rift-like extensions in the bottoms (Fig. 6D), otherwise obscured by the filling. Thus, the entire cross-sections commonly have "keyhole" shapes, with the width of the rift part from 0.3 to $3.0 \mathrm{~m}$. The lower storey of the cave, still inundated and explored only in fragments, lies along the bottom of the gypsum. It is connected with the upper level through large pits (feeders), whose morphology indicates "ascending" hydraulic communication during the cave formation period.

The cave map (Fig. 5A) displays only the upper storey passage network. Sixteen morphological regions are distinguished in the cave, according to characteristic passage size and the structural peculiarities of the patterns. The differences in passage sizes are illustrated by the specific volume parameter varying between regions from 5.1 to $16.1 \mathrm{~m}^{3} / \mathrm{m}$ (Table 2 ). 

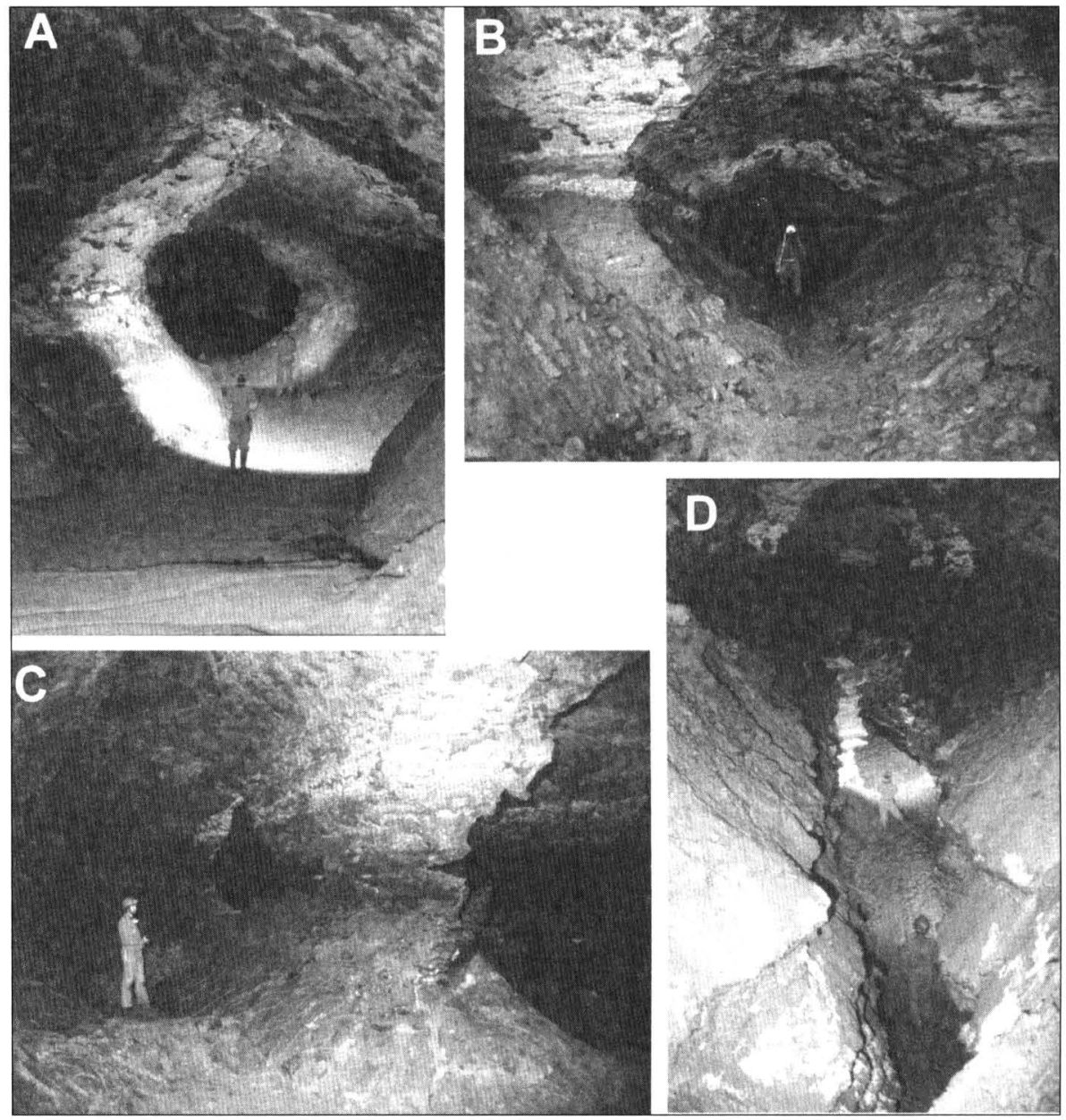

Fig. 6 - Zoloushka cave morphology. See the text for explanations. Photos by A.Klimchouk and V.Kisseljov.

\subsection{Breakdown structures}

About $70 \%$ of the maze has been covered with a special mapping of breakdown structures (BS). At least 700 breakdown structures were found in the cave, over 630 of which were mapped and documented according to the criteria outlined in the previous section. This gives an average density of breakdown structures for the whole cave field of about 1800 per $\mathrm{km}^{2}$.

Breakdown initiation. A great majority of breakdown structures initiate and develop where solution domes and cupolas have exposed the bottom of the overlying Ratynsky Limestone bed to the cave. Speleogenetically, such domes and cupolas represent the outlet features through which the water discharged from the cave during the period of transverse artesian speleogenesis. The Ratynsky bed is less than $1 \mathrm{~m}$ 
Table 2: Morphometric characteristics of the regions of Zoloushka cave and breakdown distribution by the regions.

\begin{tabular}{|c|c|c|c|c|c|c|c|c|c|c|}
\hline & \multirow{2}{*}{$\begin{array}{l}\text { Name of the } \\
\text { region }\end{array}$} & \multirow{2}{*}{$\begin{array}{c}\text { Length, } \\
\text { m }\end{array}$} & \multicolumn{2}{|c|}{ Averages } & \multirow{2}{*}{$\begin{array}{l}\text { Passage } \\
\text { area, } \\
\text { n1000m } \mathrm{m}^{2}\end{array}$} & \multirow{2}{*}{$\begin{array}{l}\text { Passage } \\
\text { volume, } \\
\text { n1000m }{ }^{3}\end{array}$} & \multirow{2}{*}{$\begin{array}{c}\text { Specific } \\
\text { volume, } \\
\mathrm{m}^{3} / \mathrm{m}\end{array}$} & \multirow{2}{*}{$\begin{array}{c}\text { Area of } \\
\text { cave field, } \\
\text { n1000 } \mathrm{m}^{2}\end{array}$} & \multirow{2}{*}{$\begin{array}{c}\text { Number } \\
\text { of BS }\end{array}$} & \multirow{2}{*}{$\begin{array}{c}\text { BS } \\
\text { density } \\
\text { per km }\end{array}$} \\
\hline & & & $\begin{array}{c}\text { Width, } \\
\text { m }\end{array}$ & $\begin{array}{l}\text { Height, } \\
\text { m }\end{array}$ & & & & & & \\
\hline 1 & Privkhodovoj & 5,600 & 2.7 & 2.2 & 15.2 & 33.8 & 6.0 & 39.2 & 105 & 2,679 \\
\hline 2 & Zabludshikh & 4,330 & 2.4 & 2.7 & 10.5 & 28.7 & 6.6 & 30.3 & 42 & 1,386 \\
\hline 3 & Perspectiv & 1,237 & 3.5 & 3 & 4.4 & 13.3 & 10.8 & 8.7 & 31 & 3,580 \\
\hline 4 & Chernovitskij & 3,919 & 3.7 & 3.2 & 14.4 & 45.7 & 11.7 & 27.4 & 68 & 2,479 \\
\hline 5 & Majsky & 1,424 & 2.1 & 2.7 & 3 & 8.1 & 5.7 & 10.0 & 15 & 1,505 \\
\hline 6 & Central'ny & 7,880 & 2.6 & 2.9 & 20.3 & 59.7 & 7.6 & 55.2 & 14 & 254 \\
\hline 7 & Zapadny & 5,015 & 2.8 & 2.7 & 13.6 & 38.4 & 7.7 & 35.1 & 26 & 741 \\
\hline 8 & Anakonda & 3,891 & 2.7 & 2.9 & 10.5 & 30 & 7.7 & 27.2 & 50 & 1,836 \\
\hline 9 & Vesely & 5,317 & 2.2 & 2.3 & 11.8 & 27 & 5.1 & 37.2 & 59 & 1,585 \\
\hline 10 & Metropoliten & 2,337 & 3.7 & 3.7 & 8.6 & 37.6 & 16.1 & 16.4 & 5 & 306 \\
\hline 11 & Ozerny & 4,228 & 3.1 & 3.8 & 12.9 & 49.1 & 11.6 & 29.6 & 38 & 1,284 \\
\hline 12 & Gotichny & 4,091 & 3 & 4.5 & 12.4 & 56.2 & 13.7 & 28.6 & 63 & 2,200 \\
\hline 13 & Vostochny & 4,769 & 3.1 & 3.6 & 14.7 & 53.1 & 11.1 & 33.4 & 60 & 1,797 \\
\hline 14 & Dal'nevostochny & 2,414 & 2.3 & 3.4 & 5.6 & 19 & 7.9 & 16.9 & 21 & 1,243 \\
\hline 15 & Kamtchatka & 1,084 & 2.4 & 2.4 & 2.6 & 6.3 & 5.8 & 7.6 & 40 & 5,271 \\
\hline 16 & Geochimichesky & 5,000 & 2.6 & 2.5 & 16 & 30 & 6.0 & 35.0 & & \\
\hline & TOTAL & 62,536 & & & 176.5 & 536 & & & 637 & \\
\hline & AVERAGE & & 2.8 & 3.0 & & & 8.8 & & & 1,876 \\
\hline & $\begin{array}{l}\text { Correlation } \\
\text { between BS } \\
\text { number and } \\
\text { the variables }\end{array}$ & 0.31 & 0.05 & -0.16 & 0.36 & 0.2 & -0.14 & & & \\
\hline
\end{tabular}

thick and is normally rather densely fissured and brecciated. It falls readily when exposed from below by the outlet features, giving rise to the formation of BS. In places where the Ratynsky bed is coarsely fractured and exposed by occasional block fall-ins, it provides an effective support for the ceiling. It is likely that most of BS in the cave was initiated during the period of transition from confined to unconfined conditions, due to the loss of buoyant support.

Mechanisms of the breakdown development. Among the structures examined, none was found to display signs of a single massive collapse of the cave roof and overburden. All BS demonstrate more or less prolonged multi-stage development. This is determined mainly by the stratified nature of the coverbeds. Five to six distinct stages are distinguished in the breakdown formation (Fig. 7).

The preparatory stage is not considered as a part of the breakdown mechanism proper, although it creates distinctive morphogenetic features, namely the outlet features (dome shafts, domes and cupolas) favoring breakdown occurrence. This stage coincides with the late artesian speleogenetic stage, and is marked by the growth in the area of the Ratynsky bed exposures at the vaults of outlet domes and cupolas.

The first stage of breakdown-proper is the failure of the Ratynsky bed into the cave and the formation of a breakout (gravitational) cupola in the lower part of the Kosovsky Formation (up to 1 to $2 \mathrm{~m}$ above the gypsum top). It is, therefore, the stage of active development. A breakdown pile consisting of the limestone blocks and 


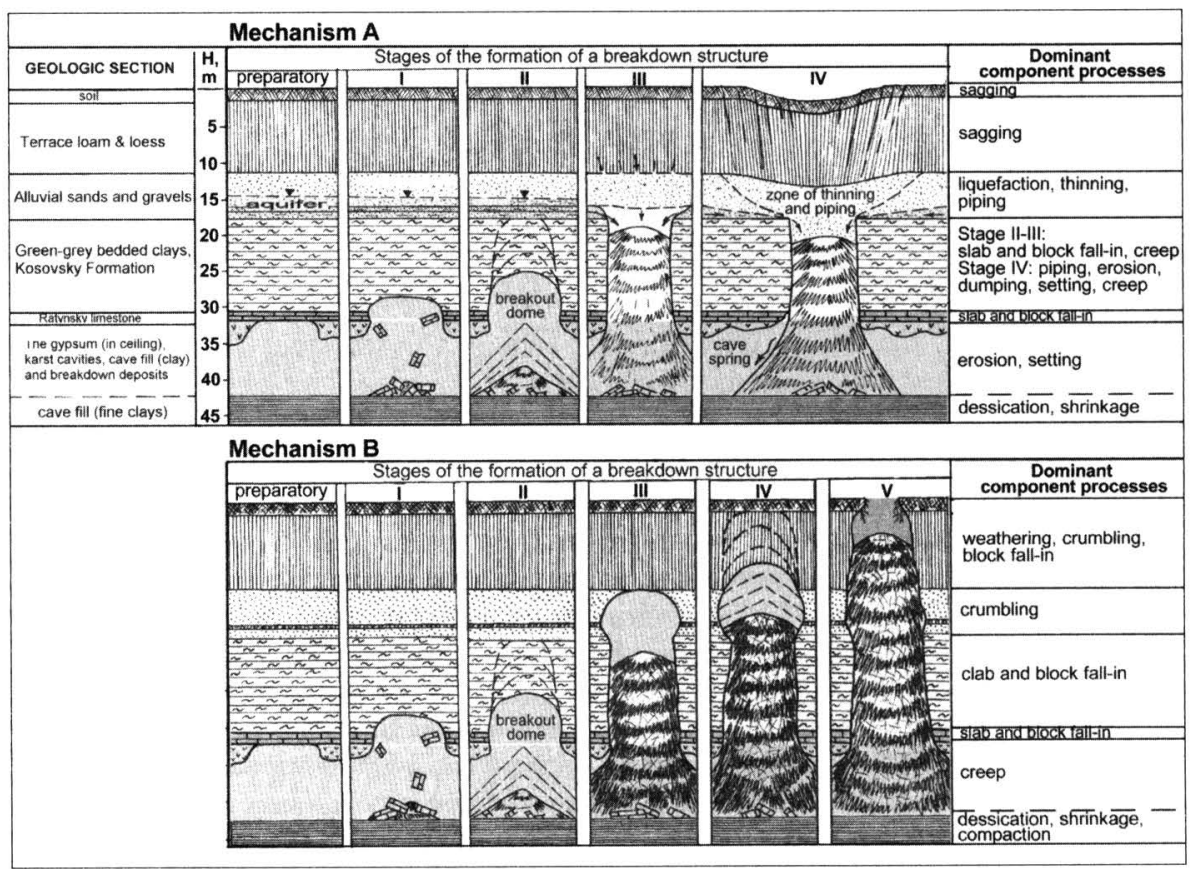

Fig. 7 - Mechanisms of the breakdown formation in Zoloushka cave.

some clayey debris is formed beneath a cupola. The first stage itself can be short, probably one fall-in event in many cases, but it is followed by a prolonged period of relative stability (second stage).

The second stage is marked by gradual upward stoping of a breakout cupola through the Kosovsky Clays. Destruction of the material at the cupola vault occurs as slab and chip breakdown, rarely as block breakdown (i.e. fallen rock masses span more than one bed; White and White, 2000). The fallen argillaceous material forms distinct breakdown taluses (cones) that can vary in volume from a few to many tens of cubic meters. This stage can span quite long periods, probably in the order of thousands to tens of thousands of years. Its duration depends upon the local properties of the Formation and its thickness in a given cave region; the latter varies between a few to $60 \mathrm{~m}$, depending on the local relief. Many breakdown structures at this stage still provide access from the cave to a stoping cupola, although when the structure reaches some height, it gets separated from the cave by a breakdown pile. Because of this, one can estimate further migration of the void and passage of BS to the next stage only on the basis of the composition of the talus material at the base. If it contains some admixture of sandy-gravel material, then the BS has reached the Quaternary bed and passed to the next stage.

The third stage begins when a migrating void has reached the sandy-gravel bed of Quaternary alluvium. Two distinct mechanisms of the further development are revealed (Figs. 7, A and B). Which one occurs in a given locality depends on the presence of groundwater in the Quaternary sandy-gravel bed. Mechanism A predominated in the past, probably during the period commencing some tens of thousands years 
ago when the Miocene aquifer lost its confinement (i.e. when breakdown processes had intensified for the first time due to the loss of buoyant support). This continued until some 40 to 30 years ago, when breakdown development intensified again due to the start of quarrying and pumping, and related lowering of the water table and subsequent transformations in the cave system. Mechanism B predominates now, when the Quaternary aquifer is largely drained across most of the area, as breakdown structures and exploration boreholes provided numerous points of vertical leakage through the Kosovsky Formation.

Mechanism A: When a migrating void reaches a sandy-gravel bed that contains groundwater, hydrodynamic component processes, such as liquefaction, piping and erosion become involved in the overall breakdown development and become predominant during the third and fourth stages. Breakdown of the last remaining portion of the Kosovsky Clays, along with some sandy-gravel material, causes liquidation of a void at the top of the BS because of sand liquefaction and the formation of a zone of thinning that extends laterally along the sandy horizon as a reversed wide-angle cone (the fourth stage; see Fig. 7A). The vertical breakdown structure enables leakage of the water from the aquifer, accompanied by further material removal by piping and erosion. Wetting of the clayey column causes its settlement down into the cave, further increasing the zone of thinning. All this leads to sagging of the overlying loam sequence, with the eventual appearance of surface deformation in the form of gradual subsidence. The rate and the depth of surface subsidence depend on the intensity of the leakage and piping, and on the rate of the erosion and settling of the breakdown column.

It is important to stress that Mechanism A results in a gradual subsidence type of the surface deformation, not collapse. Analysis of historical data and large-scale topographical maps for the pre-quarrying period supports the view that gradual subsidence was the prevailing type of deformation in the recent past. However, Mechanism A is still operative in a few breakdown structures where Quaternary beds still host lenses of groundwater. This is indicated by active filtration along some breakdown columns. There have been occasional direct observations of drastic activation of a breakdown cone, with apparent settlement and extrusion of wet clays down into the cave and release of a considerable amount of water within few hours. On the surface the related pre-existing gentle subsidence was reactivated, with the formation of fresh concentric cracks up to $2 \mathrm{~m}$ deep and up to $0.3 \mathrm{~m}$ wide.

Mechanism B: This occurs where the Quaternary sandy-gravel horizon is drained and does not contain water. This situation has become increasingly predominant in the cave area since the start of quarrying and related groundwater abstraction from the main Miocene aquifer. This caused reactivation of pre-existing breakdown structures and formation of new ones that, together with numerous exploration boreholes, created a closely spaced pattern of leakage points from the perched Quaternary aquifer. This eventually caused the aquifer to drain throughout most of the area.

The differences between the mechanisms start from the third stage (see Fig. 7B), which begins when a stoping void reaches the sandy-gravel bed. This stage signifies a non-equilibrium state. The void does not transform into a thinning zone as in Mechanism A but instead it grows quickly by crumbling until it reaches the overlying loam horizon that is able to support arching. 
The fourth stage (quasi-equilibrium state) includes further void stoping through the loam horizon. It occurs gradually by crumbling. As the void approaches the soil horizon, the destruction process is increasingly influenced by daily and seasonal changes of temperature and moisture content.

The fifth stage (non-equilibrium state) occurs in most cases as a single catastrophic event, i.e. as a collapse of the remaining roof of a void, with eventual appearance of the surface feature. Depending on local conditions, it can occur either when some part of the loams still remains at the roof or when arching is supported solely by the soil horizon. The latter case is common (with a roof thickness of about 0.3 to $1.0 \mathrm{~m}$ ), as rhizomes reinforce the soil in unploughed areas. Failure can be induced by extreme wet or dry periods, seismic events (blasting in a nearby quarry), application of additional load and ploughing. It is quite common that formation of concentric cracks and shallow subsidence precedes collapsing. Final collapse events are commonly accompanied by noise and dust ejection. This indicates that the roof collapses into a void that is already separated from the main cave. The newly formed collapses have a diameter of 3 to $5 \mathrm{~m}$, depth of 2 to $5 \mathrm{~m}$ and a bottle-like cross section (the diameter at the base is 10 to $40 \%$ larger than the diameter at surface level).

The full development sequence is described above. However, some variations are possible toward the reduction of the number of stages due to: 1) the presence of structural or lithological discontinuities and irregularities in the overburden and, 2) incomplete thickness and composition of the overburden, such as in the lower (IId) terrace, where the Kosovsky Formation is only a few to $10 \mathrm{~m}$ thick and the sandy-gravel and loam beds are entirely removed. Also, the last stage, that is the appearance of the subsidence or collapse at the surface, may never occur where the thickness of the overburden is large enough to cause self-liquidation of the stoping void (this point is discussed further below).

Distribution of breakdown structures. The resultant map shows most of the breakdown structures existing in the cave field, regardless of whether or not they are expressed at the surface (Fig. 8A). The mapped breakdown structures were classified according to their stages of development, as described above.

The survey data suggest that the overall density of breakdown structures for the whole cave field is more than 1800 per $\mathrm{km}^{2}$. However, this parameter varies substantially between cave regions, from $254 \mathrm{BS} / \mathrm{km}^{2}$ in the Central'ny region to 5271 $\mathrm{BS} / \mathrm{km}^{2}$ in the Kamchatka region. As the regions differ in size and morphology of passages and in the characteristics of their patterns, it is important to examine possible relationships between the number of breakdown structures and parameters of passages and their patterns in particular regions. Respective correlation coefficients are given in the last row of Table 2.

As can clearly be seen all the variables characterizing passage size show no appreciable correlation with the BS number. This agrees well with observations in the caves. Whereas some of the largest cave passages (up to $20 \mathrm{~m}$ wide and $10 \mathrm{~m}$ high; see photos on Fig. 6 for instance), being closely spaced and separated by only small pillars, host no or few breakdown structures, other much smaller passages contain many breakdowns. It is further illustrated by some details of the dataset under examination. The Metropoliten region, which consists of large passages (specific volume $16.1 \mathrm{~m}^{3} / \mathrm{m}$ ) has one of the lowest breakdown structure densities $\left(306\right.$ per $\mathrm{km}^{2}$ ), whereas the Kamchatka region, with a specific volume of $5.8 \mathrm{~m}^{3} / \mathrm{m}$ has the highest 

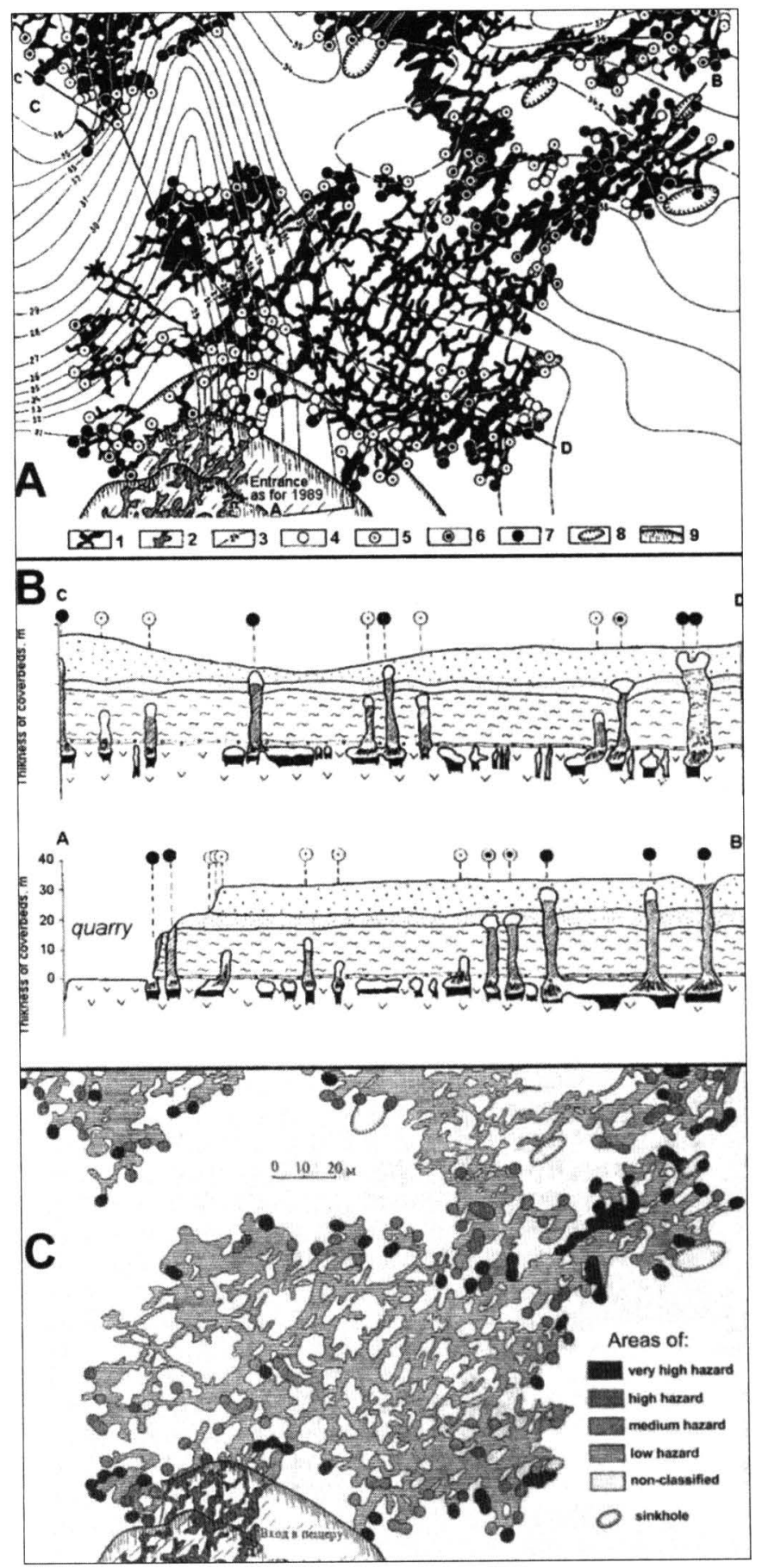

Fig. 8 - The fragment of the map of breakdown structures in Zoloushka cave (A), the profile showing different stages of their development - the heights of their propagation to the surface $(B)$ and the map of micro-zoning of the territory according to subsidence hazard. A key to the Fig. 7A:

$1=$ cave passages;

2 = passages destroyed by the quarry;

3 = isopachytes;

$4-7=$ breakdown structures with the breakout cavities positioned at various levels: 4 - at the bottom of the Ratynsky bed, 5 - within the Kosovsky Clays, 6 within the sandy-gravel bed, 7 - within the loam bed;

$8=$ surface karst features; $9=$ the quarry faces 
breakdown density. The above finding is in striking contrast with established views, which suggest that breakdown formation is controlled primarily by passage size.

The lack of correlation between BS number and passages size agrees well with the observation, mentioned above, that the vast majority of breakdowns in the cave initiate and develop from solution domes and cupolas that expose the bottom of the overlying Ratynsky limestone bed to the cave. Even a rather small-sized outlet cupola that exposes a few $\mathrm{m}^{2}$ of the Ratynsky bed may give rise to the formation of breakdown structures. In contrast, large spans of master passages tend to remain stable if no outlet features occur. The causal relationship of breakdown formation and the outlet features is discussed further below, in more general speleogenetic terms.

Site-specific collapse/subsidence hazard assessment. As the BS development stage signifies a certain level reached by a stoping void in a given geological crosssection, one can readily deduce the depth of a void position below the surface by superimposing the isopachyte map on the breakdown map (Figs 9, A and B). These data allow the main questions of engineering karstology, about where and at what depth voids stoping through the overburden located, to be answered with great precision. Adopting a hazard categorization based on an understanding of the breakdown mechanisms, one can produce a map of the micro-zoning of the territory according to the degree of subsidence/collapse hazard presented at the surface (Fig. $8 \mathrm{C}$ ). On this map some arbitrary categorization of the hazard is used that reflects the depth of the stoping void below the surface and a relative probability of the collapse/subsidence deformation at the surface. Areas of low, moderate, high and very high hazard are distinguished. Depending upon the overburden thickness, the same breakdown stages can cause different degree of hazard: the lower thickness, the earlier stage can result in the surface appearance of the collapse. The blank areas within the cave field are non-hazardous, although the blank areas outside the cave field limits are non-classified, and because of this, evaluation is based on the direct mapping in the cave. Hence, the areas outside cave field cannot be assessed in the same way.

Another question important to hazard assessment is that of the possible size of collapse/subsidence when it appears to the surface. The answer can be inferred from the above description of the breakdown mechanisms. The main gauging factor is the diameter of the outlet domes/cupolas, initiating breakdown at the level of the cave. Most commonly it varies between 1 and $5 \mathrm{~m}$. The processes involved during the first three stages result in upward stoping without appreciable increase of the void at the top of the breakdown column. Mechanism A (the subsidence mechanism) implies a possible increase of the subsidence-prone zone of 2 to 3 times, because of lateral extension of the thinning zone in the aquiferous sandy horizon. This determines the expected size of subsidence at the surface to be within a few to $15 \mathrm{~m}$. Development according to Mechanism B (the collapse mechanism) can cause an increase in the expected diameter of the surface collapse in only 30 to $50 \%$ of the initial breakdown column diameter. Hence, the possible collapse size is 2 to $8 \mathrm{~m}$, which agrees well with the actual sizes of newly formed collapses.

\subsection{The Dan'kivsky collapse}

The Dan'kivtsy area is located $12 \mathrm{~km}$ north of Zoloushka Cave, still within the subjacent karst zone. The Collapse formed suddenly, on January 11 1998, on a gen- 


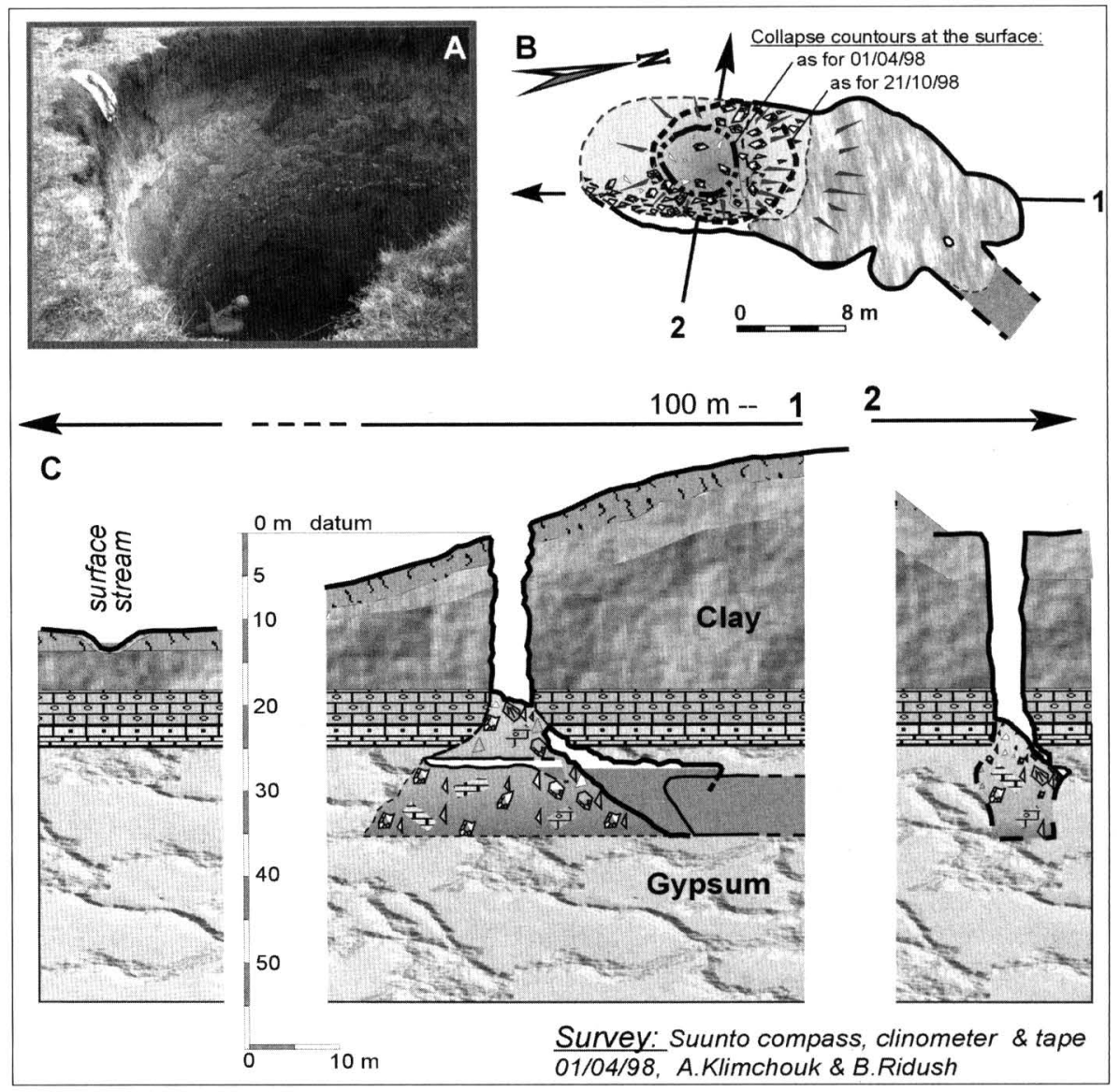

Fig. 9 - The Dankivsky Collapse, an example of the sudden single-event collapse: A - the collapse shaft at the surface in three month after the formation, B - plan, $C$-profiles.

tle slope of a small stream valley. According to local people the noise of the collapse was heard at a farm lying about $1 \mathrm{~km}$ from the site. A $22 \mathrm{~m}$-deep shaft has formed, with an open entrance to a cave at the bottom (Fig. 9A). The shaft walls exposed the clays of the Kosovsky Formation, which graded into loams in the upper part. The walls displayed fragments of slickensided rock, which suggests that the collapse occurred along a fault. This is also supported by the presence of leakage patterns at the contact between the soil and loams in the upper part of the walls, which indicate prolonged vertical percolation along the fault at the site of the subsequent collapse.

The bottom of the shaft was almost entirely occupied by breakdown material. Its arrangement (the presence of large blocks of clay with fragments of slickensided material) suggests a single-event collapse. From the top of a breakdown pile it was possible to climb down into a chamber, a widened and domed part of the passage where $1.5 \mathrm{~m}$ airspace occurred in the otherwise totally inundated cave (see plan and profile on Fig. 9, B and C). A water-filled passage, about 8 to $9 \mathrm{~m}$ wide and $7 \mathrm{~m}$ high 
continued in a NE direction. The cave was surveyed in April, and in May it became inaccessible due to the continuing filling of the entrance shaft by loose sediments. By October, the shaft was already transformed into a bowl-shaped sinkhole $4 \mathrm{~m}$ deep. It is evident that this surface feature will soon assume a gentler shape, quite similar in morphology to numerous subsidence features identified in the vicinity.

The sinkhole mouth lies at an altitude of $173 \mathrm{~m}$, some $8.3 \mathrm{~m}$ above the bottom of the small valley and $67.3 \mathrm{~m}$ above the floor of the Dniester Valley some $5 \mathrm{~km}$ to the north. The bed of the surface stream in the local valley is $19.2 \mathrm{~m}$ above the groundwater table exposed in the cave, so that the stream is perched on the clays above the vadose zone. In April, the water table was at $2.7 \mathrm{~m}$ below the top of the gypsum.

The form of the documented part of the cave suggests that it is a fragment of an extensive maze cave system analogous to Zoloushka Cave. Morphology and passage size are quite similar. This analogy is also supported by geophysical survey results indicating a labyrinthine pattern in the vicinity of the collapse.

The Dan'kivsky collapse exemplifies a rare case of a sudden single-event collapse. It occurred along a prominent fault (probably two closely related faults) at a locality where the presence of the underlying enlarged cave passage with a cupola (an outlet?) had reduced stability to a critical level. Percolation along the fault had reduced friction within the clay along the fault plane, and this further conditioned the collapse to occur through the entire thickness of the clays.

Another important lesson from the Dan'kivsky case is that the shape of a surface form is not necessarily indicative of its collapse (sudden) or subsidence (gradual) origin. With the presence of soft sediments within the overburden, an original collapse shaft can be transformed into a gentle-sloped doline within few years.

\section{Breakdown development in the entrenched karst zone: Mlynki, Slavka and Verteba caves}

The zone of entrenched gypsum karst in the Western Ukraine lies mainly to the north of the Dniester valley (Podol'sky region). The deeply incised river valleys of Dniester and its left sub-parallel tributaries separate the Miocene sequence into a number of isolated deeply drained interfluves where the gypsum and clay overburden remain largely intact. The Miocene sequence is almost entirely drained and only in the central parts of the inter-valley plateaus do the sub-gypsum units contain unconfined underground water, locally occupying also the lowermost part of the gypsum. Maze cave systems in the gypsum are presently relict. Modern dissolution is restricted to the lower part of gypsum, where the water table is present, at rare points of focused vertical percolation (where vertical dissolution pipes develop) and along short linear underground streams that are fed via swallow holes that receive periodic surface flow. Sinkholes are generally few within the high interfluves, but their density increases locally where the capping clays are removed, as within high river terraces or the floors of perched valleys.

When compared to the settings of the Zoloushka area there are some distinctly different features in the litho- and hydrostratigraphy of the overburden, and these are important to breakdown development:

- The 2 to 5 m-thick Upper Badenian unit, which immediately overlies the Ratynsky bed, is composed of marly lithothamnion carbonates (the Ternopol'sky 
beds). This material is capable of crumbling gradually, to support breakout cupola development.

- The formation lying next above is represented by massive, rather homogenous, fine marine clays (the Lower Sarmatian) up to $60 \mathrm{~m}$ in thickness depending on local relief. This material is quite coherent when dry, and if it is thick enough it can prevent further upward migration of a void. However, where wet (along tectonic or stratigraphical discontinuities that support groundwater percolation across the otherwise almost impervious thickness), it demonstrates a kind of viscous-flow behavior, and can be extruded into the cave through breakdown structures, like toothpaste from a tube. Also, the Sarmatian clays can shift down as blocks, by sliding between two closely spaced faults if cave and breakdown development result in a decrease of support from below.

- Alluvial pebble/gravel sediments of the ancient upper terraces of Dniester occur overlying the clays. In most of the region these are effectively drained due to the high degree of erosional dissection. Hence, Mechanism A of the breakdown development described for the Zoloushka Cave area does not operate in the Podol'sky region.

These peculiarities lead to some distinctive variations in the breakdown development in the entrenched karst zone, as compared to the development in the subjacent and deep-seated karst zones described above.

\subsection{Mlynki Cave}

The cave lies at the northern edge of the entrenched karst zone. The entrance opens into a valley slope within the gypsum outcrop. The thickness of the overburden increases to 25 to $30 \mathrm{~m}$ towards the plateau. Only two sinkholes are recorded at the surface within the explored cave field.

The cave is a maze, currently surveyed for $26 \mathrm{~km}$, in which passages occur on two levels. In the upper level the passages are mainly slot-like in shape, 1 to $2 \mathrm{~m}$ wide and up to $5 \mathrm{~m}$ high. In the lower level passage cross-sections are commonly wider, and many have a rift extension down to the base of the gypsum.

Complete mapping of breakdown structures has been performed for five cave regions, enabling estimation of density values. In total, 144 breakdown structures have been mapped (Fig. 10). In 57 cases breakout cupolas at the top of BS are positioned within the Ternopol'sky carbonate bed and are accessible from the main cave. In 87 cases migrating voids are separated from the cave by breakdown talus. Only in few breakdown structures is the Sarmatian clay identified in the talus, indicating unambiguously that the stoping void had entered the clay thickness above the Ternopol'sky bed. Almost all breakdown structures in Mlynki Cave developed from outlet cupolas (see photos on Fig. 4, A and B).

The extrapolated density of breakdown structures varies from 700 to almost 3000 per $\mathrm{km}^{2}$ between cave regions, with the average value for the whole set being 1609 . These characteristics are quite similar to Zoloushka Cave despite the many differences in passage size, morphology and geohydrological setting. This can be explained by the similarity of the initiation conditions, by the fact that in both cases breakdown structures initiate from outlet cupolas/domepits. Hence, these morphogenetic features impose the most important control of breakdown initiation and distribution. However, in contrast to the Zoloushka area, most of the breakdown struc- 


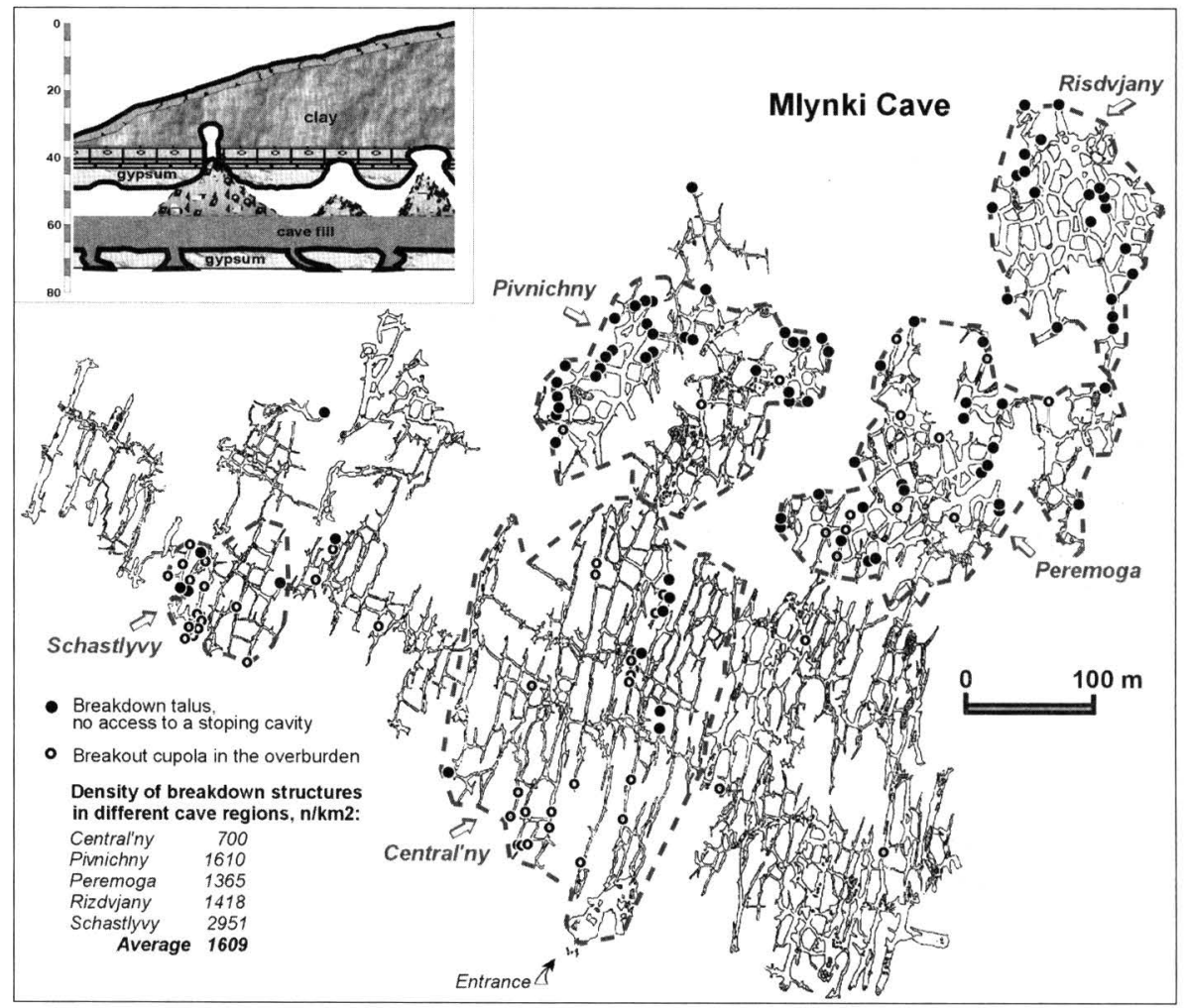

Fig. 10 - Breakdown structures in Mlynki Cave. The cave map is a courtesy of the Chortkiv Speleological club. Breakdown survey has been performed with an assistance of Vladimir Snigur

tures do not reach the surface and they remain stable and hidden in the subsurface after reaching the base of the Sarmatian clay. This reflects the fact that both the cave and the overburden are fully drained and do not demonstrate any considerable hydrogeological activity.

\subsection{Slavka Cave}

The cave lies within a spur of the interfluve plateau, bordered by a stream valley and its two small tributaries - perched karst valleys. The entrance is a collapse sinkhole on the slope of one such valley. Overburden thickness increases to 20 to $25 \mathrm{~m}$ toward the interfluve. The cave is currently explored for $9.2 \mathrm{~km}$ and consists mainly of high (3 to $10 \mathrm{~m})$ slot- and rift-like passages. Feeder conduits, commonly separate, form a lower level, relative to the master passages; in places they form small networks.

Breakdown structures in Slavka Cave are of two types: 1) "common" breakdowns formed from outlet features, and 2) breakdowns related to "rhythmolitic" bodies (see below). The latter represent a special case of breakdown formation, occurring widely in Slavka Cave but rare in other caves. 
"Rhythmolites" is the local term for highly gypsiferous bodies of closely interbedded aleurolits, sands and coaly streaks occurring within the upper part of the gypsum. Such bodies can be of 5 to $10 \mathrm{~m}$ across and 3 to $4 \mathrm{~m}$ in vertical thickness. Although "rhythmolite" bodies are found in many other caves in the region, they are unusually abundant throughout the Slavka cave field. Their contact with the gypsum is irregular and generally has a cone- or bowl-like shape. The nature of the "rhythmolite" bodies is not well understood, but one can assume that they are paleokarstic (syngenetic?) features.

Being particularly brittle, closely stratified and fissured, slabs of rhythmolitic material fall readily into any passage whose ceiling has intersected the bodies from below, giving rise to breakout cupolas/domes (see Fig. 4C). Breakdown piles beneath these consist almost entirely of rhythmolite slabs. In total 42 breakdown structures of this type were mapped within the cave (Fig. 11), giving an extrapolated density of about 480 features per $\mathrm{km}^{2}$. Most breakout forms are confined to the rhythmolite bodies or terminate at their contact with the overlying Ratynsky limestone or Ternopol'sky unit. Examination of such cupolas and domes suggests that breakdown structures of this type are not related to any discontinuities in the overlying formations; the latter remain largely intact above such breakdown. The scarcity of surface subsidence and collapse features above the Slavka Cave suggests that this type of breakdown structure is generally not sufficiently potent to produce a surface expression, despite the overburden being of rather small thickness. Considering that rhythmolite bodies are not common in other cave areas examined, this type of geological influence on breakdown initiation can be regarded as site-specific.

"Common" breakdown structures, i.e. those formed from outlet features, are quite similar to those in Mlynki Cave. Only 13 structures of this type were found, which suggests an extrapolated density of about 150 features per $\mathrm{km}^{2}$. Both density values given above are somewhat underestimated, because some structures have probably been overlooked in the marginal parts of the labyrinth. However, it is evident that in this particular case breakdown structures related to "rhythmolites" predominate over structures related to outlet features.

\subsection{Verteba Cave}

Verteba Cave lies in the neck of a large meander of the Seret River, where the cover sediments are almost entirely denuded. Only isolated patches of the Ratynsky limestone and Ternopol'sky beds, from 1 to $3 \mathrm{~m}$ in thickness, remained within the meander, but through most of the area the gypsum is covered only by soils. Many sinkholes of cone-, bowl- and plate-like shapes are scattered throughout the area (Fig. 12).

The cave is a shallow-lying labyrinth with $7820 \mathrm{~m}$ of closely-spaced, wide but low passages (primarily due to the high level of clay cave filling) that occur within a narrow strip. Numerous breakdown structures examined in this cave fall into three groups:

1) "Common" breakdowns formed from outlet cupolas;

2) Breakdowns formed from vertical dissolution pipes;

3) Breakdowns formed along prominent vertical cracks in the cave ceiling.

Massive fall-ins of blocks are rare. Even in this shallow cave they do not cause total breakdown of the cave ceiling with sudden collapsing at the surface. Gravitational breakdown of any remaining "bridges" at the top of the cupolas and the 


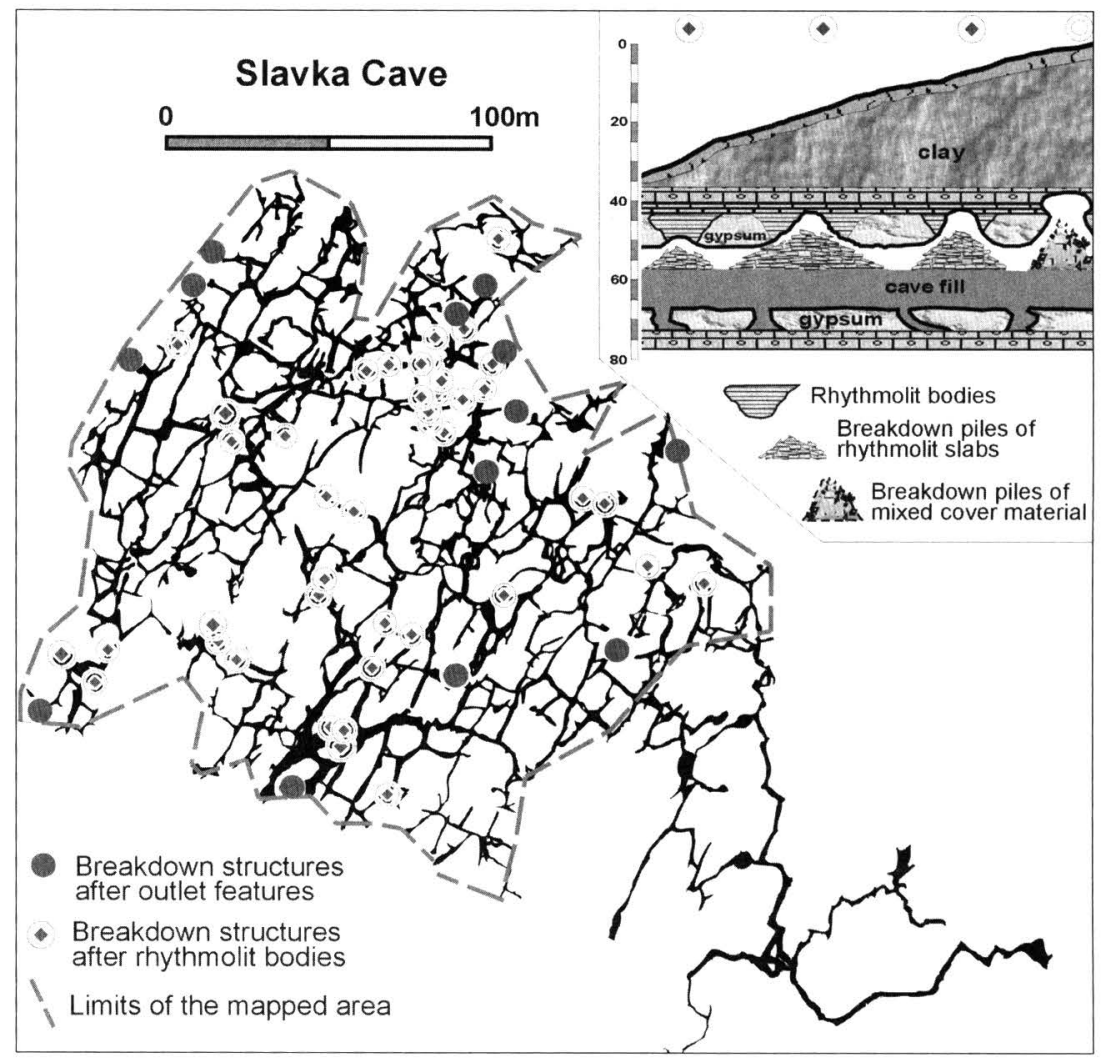

Fig. 11 - Breakdown structures in Slavka Cave. The cave map is a courtesy of the Kiev Speleological club. Breakdown survey has been performed with an assistance of Natalia Yablokova

vertical pipes is also infrequent, because of low lithostatic loads. The vast majority of breakdown structures in Verteba Cave is associated with prominent vertical cracks in the cave ceiling and involve mainly filtrational mechanisms, such as suffosion and erosion. Through such cracks, poorly consolidated fragments of the Ternopol'sky beds and remnants of the soil cover are washed into the cave, giving rise to numerous suffosion sinkholes at the surface and related breakdown piles in the caves (see Fig. 4G). The breakdown piles are rather small in size and consist of mainly (sometimes solely) of washed-in soil. Artifacts have been found in some piles, originally dumped into the sinkholes by inhabitants of the Tripil'sky settlement (about 5000 years BC) located above the cave. This gives some idea of the rate of filtrational mass flux from the surface to the cave.

\section{Discussion and conclusions}

Speleological observations have allowed the identification of several different mechanisms for breakdown development in the gypsum karst of the Western 


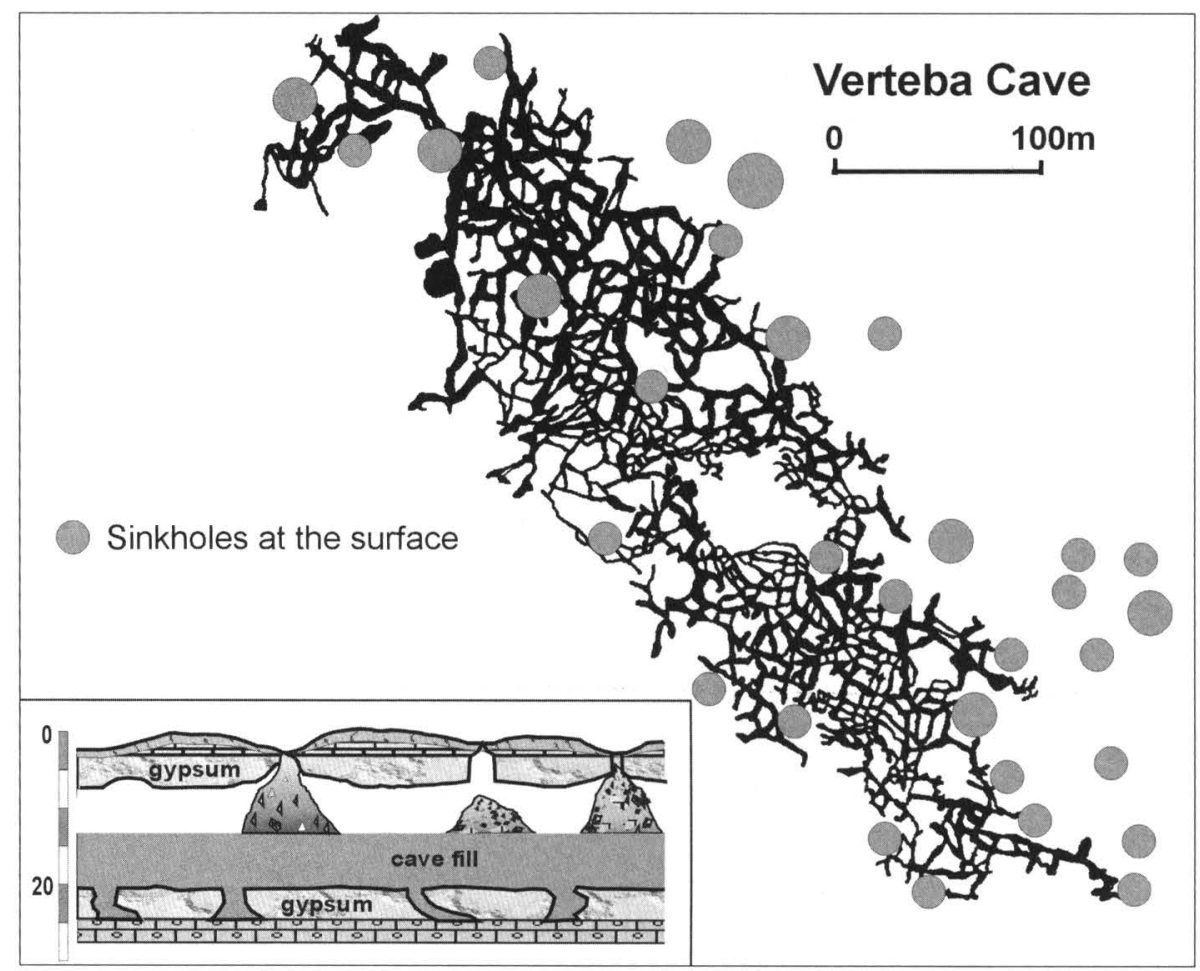

Fig. 12 - Distribution of sinkholes above Verteba Cave. The cave map is a courtesy of the Ternopil' Speleological club.

Ukraine. Distribution of breakdown structures and the mechanisms of their development are influenced mainly by:

1) Speleogenetic factors (distribution, type and size of the breakdown-initiating cavities or their particular components);

2) Lithological and structural discontinuities in the gypsum encountered by caves (combined speleogenetic and geological guidance);

3) Lithostratigraphy of the overburden and the geotechnical properties of its individual units;

4) Lithological and structural discontinuities in the overburden;

5) Hydrogeological conditions at the level of the gypsum and in the overburden.

\subsection{Breakdown initiation}

Ultimately karst breakdown development is related to the presence of karstic cavities and dissolutionally enlarged fissures. However, in contrast to established views, this study suggests that breakdown initiation in the Western Ukraine is not guided directly by the size of cavities. Some of the largest passages and chambers in the major caves remain stable and untouched by gravitational destruction. In many other cases breakdown of large gypsum blocks occur from the ceiling of passages, but the 
respective breakout surfaces remain stable, still within the gypsum (corresponding to particular prominent bedding planes). Even when the breakout surface occurs along the base of the Ratynsky bed, it remains stable in many cases. Only in rare situations can the massive breakdowns terminating some large passages be assumed to form as single-event collapses of the cave roof. Apparently, such cases are guided mainly by geological factors. This survey suggests strongly that the great majority of breakdowns initiate at specific speleogenetically or geologically "weakened" localities (factors 1 and 2 in the list above) that classify into few distinct types.

Speleogenetic controls. In the Western Ukrainian caves, two types of speleogenetic situations that favour breakdown initiation are distinguished, both creating exposures of the Ratynsky bed in the caves: 1) outlet features (cupolas, domes and domepits of "ascending" origin) and, 2) vertical pipes formed by free downward percolation.

In all the caves examined most of the breakdown structures initiate from outlet features. Such features represent places where water has discharged from a cave to the upper aquifer during a period of transverse artesian speleogenesis. By virtue of their hydrological function, the outlet features tend to form at places where the integrity of the immediately overlying Ratynsky bed and of the next higher formation are somewhat disrupted and, hence, permeability is enhanced. In other words, all of the most weakened zones at the gypsum/Ratynsky limestone contact were exploited speleogenetically, to form outlet features during transverse artesian speleogenesis. This is the single fundamental cause of breakdowns initiating predominantly from outlet features. Therefore, distribution of outlet features is the most important influence upon breakdown initiation. By way of contrast, the above reasoning is supported by the fact that the Ratynsky bed commonly forms relatively stable ceiling in large exposures created by occasional separation and breakdown of gypsum blocks into the underlying master passages, if this does not relate to outlet features.

The second speleogenetic situation favouring breakdown initiation is where vertical dissolution pipes form under present unconfined settings in the entrenched and subjacent karst zones. Such pipes develop at points of a focused descending percolation to the gypsum from the overlying beds. They are 1 to $3 \mathrm{~m}$ wide, extend downwards from the gypsum upper contact through the full thickness, and are commonly superimposed upon relict artesian passages (Fig. 13). Although in a different way, the vertical percolation pipes also expose the base of the Ratynsky limestone to the caves. Also, as in the case of the outlet features, the vertical percolation pipes commonly indicate weakened zones in the Ratynsky limestone bed and in the overlying formations. This is why breakdown structures are readily initiated from such pipes. The mechanisms for breakdown development remain largely the same as for the structures formed from outlet features, although some differences can be imposed by continuous active percolation, hence the erosion of breakdown structures. Active percolation facilitates upward stoping through larger overburden thicknesses. The density of vertical pipes in the main caves of the region (a few to a few tens of pipes per $\mathrm{km}^{2}$ ) is much lower than that of outlet features. However, in other regions their density is known to be much higher, for instance about 300 pipes per $\mathrm{km}^{2}$ in the Kungursky Cave area of the Urals, Russia (Andrejchuk, 1999). There, breakdown development from vertical pipes is considered to be the main cause of collapse/subsidence development at the surface. 


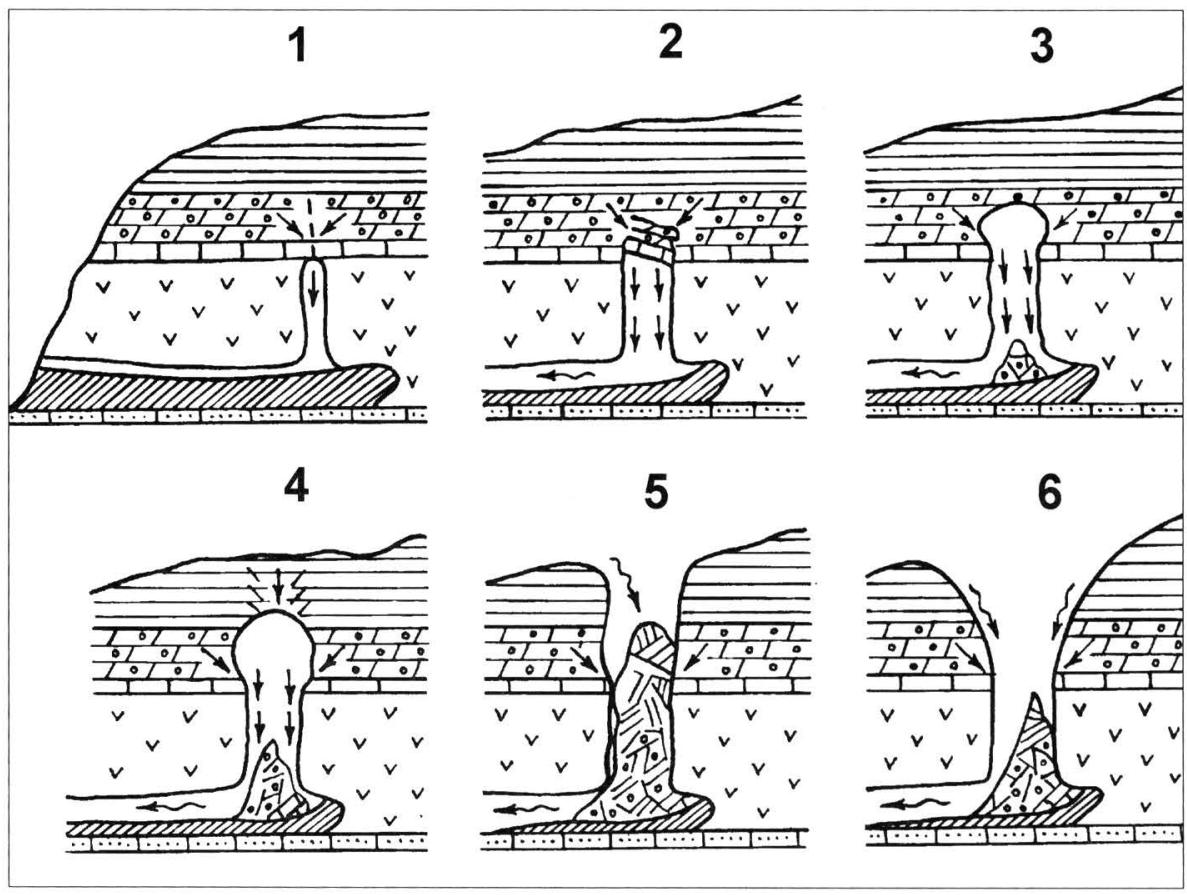

Fig. 13 - The development of breakdown structures after vertical dissolution pipes.

Geological factors. Some kinds of geological discontinuities occurring within the gypsum can initiate breakdowns in the ceilings of "normal" passages.

One type is exemplified by Slavka Cave, where most of the breakdowns relate to (palaeokarstic?) bodies of gypsum-rich "rhythmolites". Generally breakdown structures of this type are not sufficiently potent to produce an expression at the surface, even if the overburden has a relatively small thickness. Considering that "rhythmolite" bodies are not common in other cave areas that have been examined, this type of geological influence on breakdown initiation can be regarded as site-specific.

Another type of geological influence is where breakdown is initiated at points where prominent tectonic faults disrupt both the gypsum and the overburden. If faults are pre-speleogenetic, they can cause development of larger passages that may collapse suddenly when their ceiling strength is exceeded by the load of the overburden. The presence of prominent sub-vertical discontinuity planes in the overlying clays facilitates massive breakdown. It is the presence of such guiding discontinuities that allow overburden material to collapse in a single event, even where there is a considerable thickness of overburden. It is presumed that all the deep collapses known in the region are of this type. They appear at the surface suddenly, as catastrophic collapses, forming 10 to $30 \mathrm{~m}$ shafts, as exemplified by the Dan'kivsky collapse. Such collapses are quite rare both throughout this region and more generally, but they are the most hazardous, due to their considerable vertical magnitude (energy involved) and the difficulties inherent in their prediction. 


\subsection{Breakdown propagation through the overburden}

The propagation of a void through the overburden by stoping and the possibility that a breakdown structure will eventually manifest itself at the surface as a subsidence or a collapse depend on the thickness and lithostratigraphy of the overburden and on the particular mechanism involved.

Lithostratigraphy of the overburden. The presence, layered structure and lithological composition of an overburden are among the major factors that determine stages of karst breakdown development and the component processes involved, i.e. the mechanisms of karst breakdown.

Multi-stage development is governed by the stratified nature of the overburden, with varied lithological, geomechanical and hydrogeological properties for individual units. Generalizations, derived from the major publications on the problem and supported by this study, are as follows. Beds of loose, permeable sediments (i.e. sands) serve as predominantly as a setting for processes of hydrodynamic decomposition (such as suffosion, liquefaction, erosion, etc.). In contrast, low-permeability or fully-drained beds of more coherent sediment or solid rock promote arching to support void development by stoping, and serve as the setting for mainly gravitational destruction. Consequently, in the overall propagation process some non-equilibrium stages give way to quasi-equilibrium stages. The capability of some beds within the overburden to bridge a void is the main pre-requisite for collapse-style in the eventual surface deformation (as against gradual subsidence).

Hydrogeological conditions. The role of hydrogeological conditions in creating solution cavities that initiate breakdowns (speleogenetic factors) is not discussed here. However, these conditions play an important role in determining breakdown initiation (triggering) and development. In the Western Ukrainian gypsum karst, one of the most important effects that triggered breakdown development was the loss of buoyant support when the Miocene aquifer had been losing its confinement due to geomorphic development. The loss of buoyant support can disturb the metastable state of a cave roof at points where speleogenetic and geological factors have already brought its bridging capacity (resistance to failure) close to a critical level. This situation generally signifies the transition from deep-seated karst to subjacent karst. The effect is illustrated by many quarries in the deep-seated (confined) karst zone (Jazovsky sulfur quarry, Nikolaevsky clay quarry, etc.), where overburden removal and massive groundwater withdrawal from the Miocene aquifer resulted in an abrupt drop of potentiometric surfaces and dramatic intensification of collapse/subsidence formation in the vicinity of the quarries (Klimchouk and Andrejchuk, 1996).

In unconfined settings, hydrodynamic activity at the gypsum level promotes destabilization of breakdown columns that rest on the clay cave fill. Their basements can settle down, due to shrinkage and compaction of bulk cave fill, and be eroded by focused streams. In all cases this causes settlement of the breakdown columns. This is why lowering or fluctuation of the water table in the gypsum commonly activates breakdown development and subsidence formation at the surface, a case that is well exemplified by the Zoloushka Cave area. A complete draining of the gypsum promotes stabilization of the breakdown structures and slows down their propagation to the surface (the Mlynki Cave).

Another important consideration is the presence of perched aquifers within the 
overburden. In the region, an aquifer hosted in the sandy-gravel alluvial terrace sediments perched on the Kosovsky/Sarmatian clays is present in many places. In the confined karst zone it contains groundwaters almost universally throughout the area, but in the subjacent and, especially, in the entrenched karst zones it is drained in part or in full by erosion valleys and subsurface breakdown structures. Where a stoping void at the top of a breakdown structure reaches the bottom of this water-bearing horizon, the set of hydrodynamic destruction processes evolves, such as suffosion, liquefaction, erosion, etc. Besides suffosion, liquefaction and thinning occurring at the sandy horizon itself, leakage along the breakdown structure, if continuous and intense enough, may cause considerable destabilization and settling of the breakdown column due to erosion and damping, hence promoting activation of the overall process.

\subsection{Breakdown mechanisms}

The factors considered above (initiation conditions, lithostratigraphy and hydrogeological conditions) together determine the mechanisms of breakdown propagation and surface deformation. Five mechanisms identified by this study are summarized on Fig. 14. In two of them (2nd and 5th) the processes of gravitational destruction overwhelmingly predominate, but in the other three the processes of filtrational (or hydrodynamic) destruction play an important part, either in particular stages or during the entire breakdown development. Consequently these mechanisms are termed "gravitational" and "gravitational/filtrational". Note that the initiating situation only directly determines Mechanism 5, whereas other mechanisms strictly do not depend on the ways in which breakdown started. The specifics of the mechanisms are determined mainly by lithostratigraphical and hydrogeological conditions.

\subsection{The critical thickness of the overburden}

The ability of a breakdown structure to reach the surface in the form of a collapse or subsidence depends on: 1) the size of the initial "breakdown window" at the gypsum/Ratynsky bed contact and the receptacle capacity of a master cavity beneath it, 2 ) the coefficient of loosening of the fallen material, 3) the thickness of the overburden and 4) the involvement of the processes of hydrodynamic destruction.

As most breakdowns in the region initiate where artesian outlet features or vertical percolation pipes expose the Ratynsky bed to a cave, the diameter of such exposures is the main gauging factor that determines the cross-sectional size of the breakdown column. The receptacle capacity of a master passage beneath the initiating feature is determined by passage width and height. Hence, these parameters influence the initial size of a stoping void at the top of the breakdown structure.

When a breakdown talus reaches the gauging "window" and separates the migrating void from the main cave, the height of the void decreases in the course of its further upward migration, because of the loosening of the fallen material. This means that at a certain height of breakdown column void propagation may cease and the breakdown will never manifest at the surface. Hence, given some maximum parameters for the initial receptacle capacity of a cave, and a characteristic coefficient of loosening for the overburden material (it commonly varies from 1.1 to 1.3 for the region), one may speak about the critical thickness of the overburden, above which surface deformation will never occur, regardless of the degree of underground karstification. Empirical study of the relationship between sinkhole density and the thick- 


\begin{tabular}{|c|c|c|c|}
\hline $\begin{array}{c}\text { Mechanism } \\
\text { Stages, main \& component processes }\end{array}$ & $\begin{array}{l}\text { Pictogram } \\
\text { Example caves }\end{array}$ & Initiating features & $\begin{array}{l}\text { Height of propagation, } \\
\text { eventual appearance }\end{array}$ \\
\hline $\begin{array}{l}\text { 1. Gravitational/filtrational, multy-stage } \\
\text { Upward stoping: slab \& cheap breakdown, } \\
\text { crumbling } \\
\text { Sagging: liquefaction, thinning, } \\
\text { suffosion, erosion, settling }\end{array}$ & DIIIIII & $\begin{array}{l}\text { Outlet features of } \\
\text { artesian caves } \\
\text { Vertical percolation } \\
\text { pipes superimposed } \\
\text { on artesian caves }\end{array}$ & $\begin{array}{l}\text { Up to } 50-55 \mathrm{~m} \text {, } \\
\text { Gradual subsidence }\end{array}$ \\
\hline $\begin{array}{l}\text { 2. Gravitational, multy-stage } \\
\text { Upward stoping: slab \& cheap breakdown, } \\
\text { crumbling } \\
\text { Collapse: block breakdown }\end{array}$ & 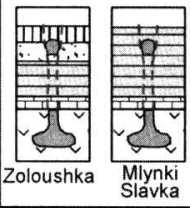 & $\begin{array}{l}\text { Outlet features of } \\
\text { artesian caves } \\
\text { Lithological and/or } \\
\text { structural discontinuities } \\
\text { in the gypsum } \\
\text { over a large cavity }\end{array}$ & $\begin{array}{l}\text { Up to } 45-50 \mathrm{~m} \text {, } \\
\text { Medium magnitude } \\
\text { collapse }\end{array}$ \\
\hline $\begin{array}{l}\text { 3. Gravitational/filtrational, multy-stage } \\
\text { Upward stoping: slab \& cheap breakdown, } \\
\text { crumbling, erosion } \\
\text { Collapse: block breakdown }\end{array}$ & 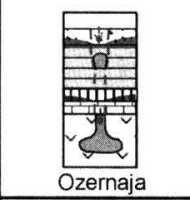 & $\begin{array}{l}\text { Vertical percolation } \\
\text { pipes superimposed } \\
\text { on artesian caves } \\
\text { Outlet features of } \\
\text { artesian caves }\end{array}$ & $\begin{array}{l}\text { Up to } 50-55 \mathrm{~m} \text { and more } \\
\text { when an intense percolation, } \\
\text { Medium magnitude } \\
\text { collapse }\end{array}$ \\
\hline $\begin{array}{l}\text { 4. Gravitational/filtrational, } \\
\text { single (?) prolonged stage } \\
\text { Sagging, suffosion }\end{array}$ & 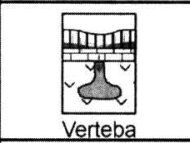 & $\begin{array}{l}\text { Vertical percolation } \\
\text { pipes superimposed } \\
\text { on artesian caves } \\
\text { Outlet features of } \\
\text { artesian caves } \\
\text { Any open fissure } \\
\end{array}$ & $\begin{array}{l}\text { Up to few meters, } \\
\text { Gradual subsidence }\end{array}$ \\
\hline $\begin{array}{l}\text { 5. Gravitational, single (?) stage } \\
\text { Massive block breakdown }\end{array}$ & 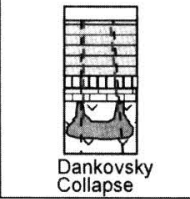 & $\begin{array}{l}\text { Structural discontinuities } \\
\text { both in the gypsum and } \\
\text { the overburden } \\
\text { over a large cavity }\end{array}$ & $\begin{array}{l}\text { Up to } 50-55 \mathrm{~m} \text { and } \\
\text { probably more, } \\
\text { Catastrophic } \\
\text { high magnitude } \\
\text { collapse }\end{array}$ \\
\hline
\end{tabular}

Fig. 14 - Mechanisms of the breakdown development in the gypsum karst of the Western Ukraine.

ness of the overburden performed for the three different areas (Fig. 15), seemingly supports this assumption. The critical thickness of the coverbeds is found to vary from 45 to $55 \mathrm{~m}$ between the three different areas. The shape of the curve for area 3 (Zoloushka Cave) differs from the other two because of the intensification of collapse and subsidence formation caused by man's impact (quarrying activity).

Apparently, the critical thickness of the overburden will be specific for each region. It depends on the size of the cavities and the structure and composition of the cover. This scheme is strictly valid, however, only for purely gravitational mechanisms that do not involve the processes of hydrodynamic destruction and removal, as the latter can maintain the non-karstic growth of a stoping void or restoration of the receptacle capacity of an initial karstic cavity. And, finally, it does not apply for situations where the cover is made of sediments that have a coefficient of loosening close to 1.0, such as sands. In sands, a stoping void can propagate through great thicknesses of up to $100 \mathrm{~m}$ or more.

\subsection{Synopsis}

Breakdown initiation at the karstified horizon (at the cave level) occurs due to various causes. Simple gravitational breakdown of blocks and slabs from the cave ceil- 


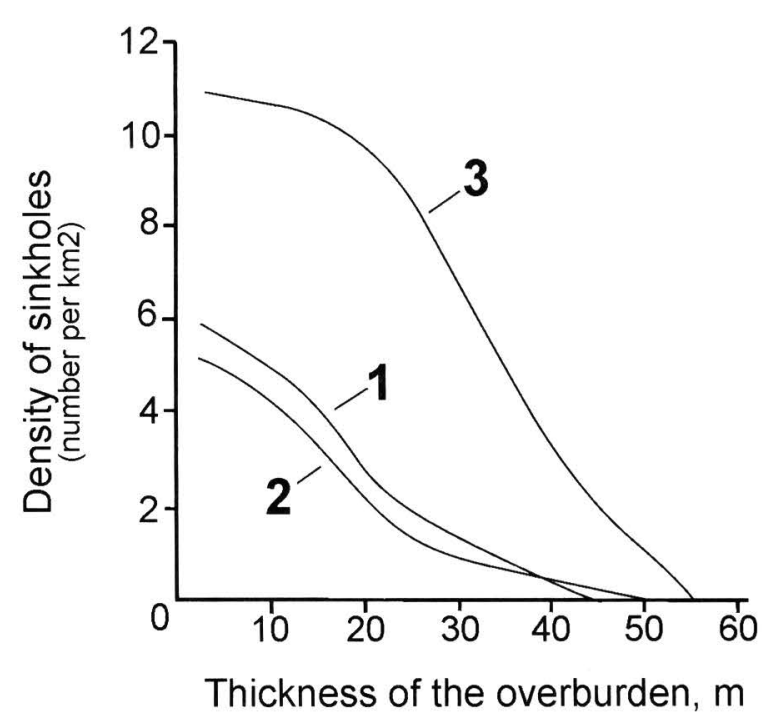

Fig. 15 - The density of sinkholes versus thickness of the overburden: $1=$ in the Seret-Nichlava interfluve (entrenched karst), 2 = in the Cherny Potok area (subjacent karst), $3=$ in the Zoloushka cave area (subjacent karst).

ing rarely gives rise to destruction of the overburden. The most important conclusion of general significance derived from this study is that breakdown of the overburden is caused predominantly by structures related to specific morphogenetic features in cave systems (outlet features), or to specific genetic types of conduits (vertical solution pipes), not merely to large unsupported roof spans. This is because, by virtue of their origin and hydrogeological function, such features exploit the points of lowest integrity within the main bridging unit (the Ratynsky bed in the Western Ukraine) and the entire overburden. This is also the reason why such breakdown structures are sufficiently potent to propagate through the overburden, whereas those related to occasional block breakdown of the cave ceilings are commonly not. Therefore, passage size is not an important influence upon breakdown initiation.

Breakdown formation can proceed through a variety of mechanisms. In the intrastratal and covered karsts, manifestation of karstic features at the surface does not adequately reflect the degree and character of karstification at depth. The shape and size of sinkholes is not indicative of their origin. Structure and composition of the cover and the processes therein play the major role in transmission of breakdowns to the surface.

This study demonstrates that speleogenetic analysis plays one of the most important roles in understanding breakdown pre-conditions and mechanisms, and in eventual subsidence hazard assessment. Direct cave observations aimed at both speleogenetic investigation and breakdown characterization at regional or site-specific levels should be employed wherever possible. 


\section{Acknowledgement}

This study was partially supported by the ROSES (Risk of Subsidence due to Evaporite Solution) Project ENV4-CT97-0603 funded by the EC Framework IV Programme. The authors sincerely thank Dr. David Lowe and Dr. Armstrong Osborne for the correction of English.

\section{REFERENCES}

ANDREJCHUK V.N. 1984. The regularities of karst development in the south-east of the zone of junction between the Russian platform and Carpathian foredeep. PhD Thesis, Chernovitsky University (russ.).

ANDREJCHUK V.N. 1988. The tectonic factor and peculiarities of the sulfate karst of Bukovina: geology, geomorphology and hydrogeology of karst. Sverdlovsk, 66 p (russ.).

ANDREJCHUK V.N. 1999. Collapses above gypsum labyrinthic caves and stability assessment of karstified terraines. Prut, Chernovtsy. $51 \mathrm{p}$ (russ.).

ANDREJCHUK V.N. and KORZHIK V.P. 1984. The Zoloushka karst system. Peshchery (Caves). Types and Metods of Investigation. Perm, Perm University: 12-25 (russ).

KLIMCHOUK A.B. 1990. Artesian origin of large labyrinth caves in the Miocene gypsum of the Western Ukraine. Doklady AN Ukr.SSR, Ser B Geol chem and biol sciences 7: 28-32 (russ).

KLIMCHOUK A.B. 1992. Large gypsum caves in the Western Ukraine and their genesis. Cave Science 19 (1): 3-11.

KLIMCHOUK A.B. 1996. Gypsum karst in the Western Ukraine. 263-278. In: Klimchouk A.B, Lowe D.J, Cooper A.H and Sauro U. (Eds.) - Gypsum karst of the World. Int. Journal of Speleology Theme issue 25 (3-4).

KLIMCHOUK A.B. 2000. Speleogenesis of the great gypsum mazes in the Western Ukraine. 261-273. In: Klimchouk A., Ford D., Palmer A. and Dreybrodt W. (Eds.) Speleogenesis: Evolution of karst aquifers. Huntsville: Natl. Speleol. Soc.

KLIMCHOUK A.B. and ANDREJCHUK V.N. 1988. Geologic and hydrogeologic conditions of the development of large gypsum caves in the Western Ukraine and their genesis. Peshchery (Caves). Gypsum and Anhydrite Caves. Perm University, Perm: 12-25 (russ).

KLIMCHOUK A.B. and ANDREJCHUK V.N. 1996. Breakdown development in cover beds, and landscape features induced by intrastratal gypsum karst. 127-144. In: Klimchouk A.B, Lowe D.J, Cooper A.H and Sauro U. (Eds.) - Gypsum karst of the World. Int. Journal of Speleology Theme issue 25 (3-4).

KLIMCHOUK A.B. et al.. 1985. The study of geological and hydrogeological conditions of karst development of the Pridnestrovsky Podolia in the connection with the estab lishment of a karstological monitoring site. 47-54. In: Sokolovskij I.L. and Klimchouk A.B. (Eds.) - Fizicheskaja Geografija i Geomorfologija, vol.32. Karst of the Ukraine. Vyshcha Shkhola, Kiev (russ.).

SHESTOPALOV, V.M. (Ed.). 1989. Water exchange in hydrogeological structures of the Ukraine. Water exchange under natural conditions. Kiev, Naukova Dumka. 288 pp. (russ.). 
WHITE E. AND WHITE W. 2000. Breakdown morphology. 427-429. In: Klimchouk A., Ford D., Palmer A. and Dreybrodt W. (Eds.) -Speleogenesis: Evolution of karst aquifers. Huntsville, Natl. Speleol. Soc. 